\title{
A görög információs társadalom
}

Az ország-jelentés szerzői megállapítják, hogy az információs társadalom Görögországban lassan fejlődik, és Görögország az EU országok rangsorának a vége felé helyezkedik el a legtöbb indikátor tekintetében. A szélessávú hozzáférés mértéke nem kielégítő, és az infrastruktúra fogyatékosságai miatt az interneten nyújtott szolgáltatások igénybevétele jóval az átlagos szint alatt van. Görögországban az IKT használatához szükséges alapvető és speciális készségek is alacsony szinten állnak. Az információs társadalom fejlesztésére számos állami kezdeményezés és program van folyamatban a szabályozás, a képzés és az infrastruktúra fejlesztése terén egyaránt. A siker egyik alapvető előfeltétele a távközlési szolgáltatási piac liberalizációjának gyors véghezvitele. A 2006-2013. évi digitális stratégia célja a Görögországot más tagállamoktól még mindig elválasztó digitális szakadék áthidalása.

Kulcsszavak: Görögország, információs társadalom, szélessávú internet-kapcsolat, távközlés, IKT

\section{Szerzői információ:}

Kerstin Siakas

Finnország svéd nemzetiségi területérốl származik. 1989 óta egy görögországi múszaki egyetem, az Alexander Technological Educational Institution E-Informatikai Tanszékének oktatója Theszaloníkiben. Kiterjedt ipari tapasztalatokra tett szert a nagy információs rendszerek multikulturális környezetben való múködtetése terén. Első egyetemi diplomáját közgazdászként szerezte Finnországban, majd a szoftverek minôségbiztosítása szakterületén doktorált az Egyesült Királyságban. Kutatói érdeklődése kiterjed az információs társadalom számos területére, különös tekintettel az információs rendszerek emberi és kulturális aspektusaira, valamint a pedagógiai kérdésekre, köztük a technológiai eszközökre alapozott távoktatási formákra.

Így hivatkozzon erre a cikkre:

Siakas, Kerstin, Themis Kotsialos. „A görög információs társadalom”.

Információs Társadalom VIII, 3. szám (2008): 82-112.

$=$ https://dx.doi.org/10.22503/inftars.VIII.2008.3.6 $\rightleftharpoons$


Kerstin Siakas - Themis Kotsialos

\section{A görög információs társadalom}

\section{Összefoglalás}

A mai gyorsan változó és intenzíven versengő globális környezetben a kormányok, a szervezetek és az állampolgárok több kihívással néznek szembe, mint bármikor azelốtt. Az Európát versenyképes tudásgazdasággá tenni kívánó lisszaboni célok szoros összefüggésben állnak az információs társadalom kiépítésével. Az információs és kommunikációs technológiák (IKT) terén bekövetkezett fejlemények és az internet kialakulása nagyban elôsegítették az információs társadalom és a média fejlődését. A világ új számítógépesített gazdaságát dinamikusan képviselik a munka új formái, például a távmunka vagy az emberek új virtuális környezetekben és „innovációs ökoszisztémákban" (a kis- és középvállalkozások globális hálózataiban) folyó együttmúködése ( $E U$ Info Sheet 7b). A technológia változásaiból és azok fóbb következményeiból adódó új kihívásokra csak mozgósító erejû́ politikával lehet megfelelố választ adni.

Ilyen irányú politikai törekvésként az Európai Unió jövóképében, amit a gazdasági ágazatok és a kormányzatok egyaránt kívánatosnak tekintenek, a média és a kommunikációs technológiák, valamint a piacok konvergenciája rajzolódik ki, amely lehetôvé teszi, hogy minden felhasználó bárhol és bármikor magas színvonalú adat-és kommunikációs szolgáltatásokat vehessen igénybe, biztonságos és könnyen hozzáférhetố környezetben (HLG 2006). Az IKT és a tömegtájékoztatási eszközök konvergenciája ${ }^{1}$ új lehetôségeket fog teremteni a szolgáltatások és az e-gazdaság fejlődésében mind az állampolgárok, mind a vállalatok számára. A hagyományos tartalmak (film, videó, zene) ma elérhetók már digitális formában is, és új digitális szolgáltatások (például interaktív szoftverek) jönnek létre. Az információs társadalmi szolgáltatások és a média, a hálózatok és a gépi berendezések digitális konvergenciája mindennapi valósággá válik (HLG 2006a). Az IKT által közvetített tartalmakat háromdimenziós multimédia-formátumban jelenítik meg egyre kisebb, biztonságosabb, „okosabb”, gyorsabb, mindig hozzáférhetố és egyre könnyebben használható készülékek. A szemünk láttára alakulnak ki a valóság új rétegeit alkotó, általánosan Web 2.0 néven ismert társadalmi és médiahálózatok, amelyekben a felhasználók hozzák létre a tartalmakat (pl. Yahoo!, Answers, Flickr, YouTube, Del.icio.us.).

A digitális konvergencia megkívánja egyrészt a politikai törekvések konvergenciáját, másrészt pedig - ahol a kialakuló digitális gazdasággal való lépéstartáshoz erre szükség van - a megfelelő szabályozási keretek elfogadását is.

Az e-kormányzati rendszerek annyiban különböznek a kereskedelmi információs rendszerektốl, hogy gyakran követnek a hatékonyság és a gazdaságosság követelményein túlmutató stratégiai célokat. Ezenkívül olyan politikai és társadalmi célokat

\footnotetext{
${ }^{1}$ A különbözô iparágak és az általuk nyújtott szolgáltatások közötti határvonalak elmosódásához vezető technológiai trendek (e-Business W@tch 2006).
} 
is szolgálnak, mint például a kormányba vetett bizalom, a társadalmi befogadás, a közösségek regenerálódása, a közösségi jóllét és a fenntartható fejlődés (GrimsleyMeehan 2007).

Az Európai Bizottság első ízben az 1998-ban kibocsátott Green Paper on Public Sector Information in the Information Society címú dokumentumban juttatta kifejezésre, hogy az uniós, nemzeti, regionális és helyi közigazgatási szinteken egyaránt meg kell teremteni az alapokat az e-kormányzat kifejlesztéséhez (SCP-5, 2007). Ahhoz, hogy Európa vonzóbb hellyé váljon a befektetések és a munka számára, szükségképpen hatékony kormányzást kell megvalósítani. A jól múködő e-kormányzati szolgáltatások elôsegítik a versenyképességet és az innovációt, lehetôséget adva a vállalatoknak (különösen a kis- és középvállalkozásoknak) a számukra releváns adminisztrációs, pénzügyi és gazdasági információkhoz való gyors és akadálytalan hozzáféréshez, ugyanis ezek hiányában, illetve az idóbeli korlátok és a pénzügyi természetú szabályozások beható ismerete nélkül a gazdasági és társadalmi szereplók nem tudnak kellő tájékozottságon alapuló döntéseket hozni. Fejlett e-kormányzati szolgáltatások megléte esetén az újonnan induló vállalkozások is gyorsabban és kevesebb költséggel jöhetnek létre. Meg kell említeni, hogy a kis- és középvállalkozások igen nagy részét teszik ki Európa gazdaságának. Az Európai Unióban múködó körülbelül 23 millió kis-és középvállalkozás alkotja az összes gazdasági vállalat 99 százalékát, és ezek együttesen körülbelül 75 millió embert foglalkoztatnak (EU ICT 2006).

Az EU e-kormányzati politikájának jelenlegi célja az információkhoz való könynyebb hozzáférés és az aktívabb állampolgári részvétel biztosítása. 2005 júniusában a bizottság kibocsátotta a „i2010 - Európai Információs Társadalom a Növekedésért és Fejlödésért 2010" (i2010 - European Information Society for Growth and Development 2010) címú új stratégiai dokumentumot (COM 229, 2005; EU Info Sheet 7.4, 2006). Az „i2010” átfogó stratégiát fogalmaz meg a gazdasági növekedés és a foglalkoztatás növelésére az információs társadalomhoz és a médiához kötődő ágazatokban, a digitális gazdaság fejlődését ösztönzô politikai eszközök alkalmazása és folyamatos korszerúsítése révén. A szabályozási eszközökön kívül ezt a célt szolgálják a kutatások és az ipari kapcsolatok is. Az „i2010” hangsúlyozza az IKT meghajtómotorként betöltött szerepét a társadalmi befogadás és az életminőség javítása terén. Az „i2010” kezdeményezés az EU információs társadalmi és médiapolitikájának kereteként az alábbi három prioritást határozza meg:

- Egységes európai információs tér megteremtése az információs társadalom és a média számára, a nyílt és versengố belsố piac támogatásával.

- Az IKT körébe tartozó innovációs és kutatási tevékenységek terén eszközölt beruházások ösztönzése a gazdasági növekedés és a foglalkoztatás fokozása érdekében.

- A mindenkit befogadó európai információs társadalom megvalósítása, amelyben lehetőség nyílik a fenntartható fejlődésre, a prioritások meghatározásával a jobb közszolgáltatások és jobb életminőség biztosításához.

A hangsúly az új technológiák kutatására és fejlesztésére, a biztonságra, valamint az adminisztrációs költségek csökkentésére kerül mind az állami, mind a magánszektorban (EKT 2007).

Az „i2010” stratégia céljai egyrészt az IKT terén folyó kutatás és fejlesztés révén, másrészt az eredményeknek az állampolgárok mindennapi életét megkönnyítố speciá- 
lis alkalmazásait felölelố kompetitív EU-programok megvalósításán keresztül érhetók el. Az IKT-kutatások finanszírozására szolgáló legfontosabb EU-program az EU hetedik keretprogramja (Seventh Framework Programme, FP7) a technológiai kutatás és fejlesztés ösztönzésére (2007-2013), amelyet az EU gazdasági növekedési és foglalkoztatási stratégiájához való fontos hozzájárulásként terveztek meg. Ezt követi az információs és kommunikációs technológiák politikai támogatásának programja (Information and Communication Technology Policy Support Programme, ICTP SP) a versenyképességi és innovációs program (Competitiveness $\&$ Innovation Programme, CIP) fontos részeként. Az ICTP SP célja a gazdasági növekedés és a foglalkoztatottság egyidejú fokozása Európában. Ezt a pénzügyi támogatási programot az alábbi eszközök alkalmazása segíti elố:

- kísérleti programok és tematikus hálózatok (beleértve a „legjobb gyakorlatok” követését szolgáló akciókat);

- politikai elemzések, fejlesztés és koordináció;

- propaganda, kommunikáció, információmegosztás, a tudás terjesztése.

A három kiemelt témacsokorba a következók tartoznak:

- e-kormányzat, öregedés és társadalmi befogadás, e-egészségügy;

- a kis- és középvállalkozások támogatására irányuló kezdeményezések, „intelligens" autók, fenntartható növekedés, a magánélet biztonsága;

- propagandaakciók, igazodási pontok kijelölése, az információs társadalom fejlódésével foglalkozó tanulmányok.

Az egyéb hasonló programok között meg kell említenünk az eContentplus programot, amelynek célja a digitális tartalmak szélesebb körben hozzáférhetôvé, könnyebben felhasználhatóvá és jobban kihasználhatóvá tétele Európában, valamint az Európa kulturális örökségének megốrzésére szolgáló „digitális könyvtár” (Digital Library) programot is. Ugyancsak az információs társadalom fejlesztésére szolgál a távtanulást elősegítő elektronikus tanulási (e-Learning) program, amely az információs és kommunikációs technológiáknak az európai oktatási és képzési rendszerekbe való hatékony integrálására irányul. Idesorolható továbbá az „e-biztonsági” ( $e$-Safety) program, amely a közlekedésbiztonság fokozása és a balesetek számának csökkentése érdekében az integrált intelligens biztonsági rendszerek bevezetésének, fejlesztésének és hatékony felhasználásának felgyorsítását túzi ki célul az európai közutakon az IKT nyújtotta „intelligens” megoldások bevezetésével. Rokon törekvések kereteként szolgál a közigazgatás, a gazdaság és az állampolgárok számára nyújtott páneurópai e-kormányzati szolgáltatások interoperabilitásának biztosítására kidolgozott program (IDABC: Interoperable Delivery of Pan-European eGovernment Services to Public Administrations, Businesses and Citizens), valamint az európai audiovizuális ipar támogatását célzó MEDIA-program is.

Görögországban a kormány igyekszik biztosítani, hogy a kialakuló információs társadalom valóban mindenkié legyen, az „információgazdagok” és az „információszegények" közötti szakadék áthidalásával ốrködve az állampolgárok jogai, valamint a kifejezés és az információ szabadsága fölött.

Az online közszolgáltatások tekintetében az alábbi két fontos tényezố kombinációja játszik jelentős szerepet (SCP 2007):

- az információs társadalom fejlesztése keretében a közigazgatási szektor által az állampolgárok és a gazdasági szereplók (vállalatok) számára nyújtott szolgáltatások modernizálása; 
- új típusú, innovatív közszolgáltatások megvalósítása az Európai Unió folyamatos megújulásának követelményét szem előtt tartva.

Valamennyi releváns dokumentum az állampolgár-központú e-kormányzat (CitizenCentred e-Government, CCeGov) megvalósítását túzi ki célul. 2007 februárjában Athénban rendezték meg a második e-kormányzati múhelytalálkozót (2nd CCeGov Workshop), amely elsősorban a hatékony közérdekú szolgáltatások megtervezésével foglalkozott, az állampolgárok mint fogyasztók viselkedésének szisztematikus tanulmányozása alapján az alábbi kérdésekre keresve a választ (CCeGov 2007; IDABC 2007):

- Kik az állampolgárok, és hol tartózkodnak?

- Mire van szükségük az állampolgároknak, és mit akarnak?

- Hogyan lehet létrehozni a megfelelő kapcsolatokat a szolgáltatások igénybevételéhez?

A múhelytalálkozón a meghívottak igen aktívan vettek részt, saját eseteiket hozva fel megvizsgálandó példaként a vitacsoportok és a megjelent szakértók eloott. Néhány példa a megvitatott témák változatosságára: az előadókkal szemben támasztott követelmények, egyes konkrét esetek, az adminisztratív és technikai eszközök, az alkalmazott tipológiák és a tanuláshoz nyújtott kollegiális segítség célszerú formái egyaránt szóba kerültek.

Görögország mindazonáltal még mindig nagy lemaradásban van (lásd az EU éves jelentését, EU Annual Report 2007). A széles sávú internet-hozzáférés megvalósítása terén az ország az EU legalacsonyabb szinten álló tagállamai között van. Az internet tényleges használatát tekintve az állampolgárok körében hasonló a helyzet. A 3G-szolgáltatások és a digitális televízió még gyerekcipóben jár. Az e-kormányzati szolgáltatások elérhetôsége szintén az európai átlag alatt van, és a múlt év óta nem emelkedik, hanem még hátrébb került a rangsorban: az állampolgárok igen csekély mértékben veszik igénybe ezeket a szolgáltatásokat. A széles sávú hozzáférés az iskolákban a legalacsonyabb szintú Európában, és ugyanez mondható el az alkalmazottak IKT-készségeiról is.

A helyzet javítására azonban fontos ösztönzô lépések történtek:

- Kidolgozták az országos digitális stratégiát, és annak alkalmazását törvénybe iktatták.

- Intenzívebbé vált az információs társadalom kiépítése.

- Az állam aktívan támogatja a digitális infrastruktúra fejlesztésére irányuló programokat, és az információs rendszerek fontos alkalmazásai valósultak meg a közigazgatásban.

- Az új technológiák felhasználásából a mindennapi életben származó előnyök tudatosítására mind az állampolgárok, mind a vállalatok körében megindult a „Digitális Hellas" címú országos kampány.

\section{Bevezetés}

Mára nyilvánvaló vált, hogy a közigazgatási rendszerek modernizálása tekintetében digitális szakadék tátong az EU bizonyos tagállamai között, amely elválasztja egymástól az elektronikus kormányzati platformokkal már rendelkezô országokat azoktól, amelyekben még csak korlátozott projektek vagy tervek vannak ezen a téren. Ebben a 
tekintetben Görögország hátul kullog. Az 1994 és 2000 közötti években az új technológiákat nem használták ki kellő mértékben a potenciális előrelépések megtételére a görög társadalmi és gazdasági életben. Ennek okai a következő fóbb csoportokba osztha-

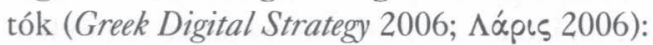

- Alacsony szintü IKT-használat. Az IKT használata a szervezeteknél igen alacsony szintú volt. Különösen a kis- és középvállalkozásoknál állt alacsony szinten az innováció, és ezek körében az innovatív elgondolások szerint folyó együttmúködés is minimális volt.

- Kevés e-kormányzati szolgáltatás. A közigazgatásnak nem sikerült hatékonyan használatba vennie az új technológiákat és tökéletesítenie a görög szervezetek számára nyújtott szolgáltatásait. Úgy tứnik, hogy ennek okai között szerepel a technológiai jövókép és a központi koordináció, valamint a technológiából a legtöbbet kihozni képes, konkrétan kidolgozott elektronikus kormányzati stratégia hiánya.

- Az IKT-profilú vállalatok alacsony szintú gazdasági közremúködése. Az IKT hozzájárulása a GDP-hez más országokhoz viszonyítva nem volt kielégítő (a 2004. évben 1,32 százalék, összevetve például Svédországgal, ahol ez az arány 4,56 százalék volt) sem az új technológiai termékek, sem az IKT-szolgáltatások tekintetében. Az oktatási intézmények és a piac közötti technológiatranszfer mértéke Görögországban más országokhoz viszonyítva szintén a legalacsonyabbak között volt (1-8-ig terjedő skálán 2004-ben 3,70 pontértékkel, míg Finnországban ugyanez a mutató 7,31 volt).

- A vállalkozók motivációjának hiánya. Azokon a területeken, amelyek általában a legjobban képesek kihasználni az IKT-eszközöket, nem ösztönözték eléggé a vállalkozói szellem érvényesülését, hanem ehelyett a hagyományos kis- vagy nagyon kicsiny vállalkozásokat támogatták. Az új vállatok létrehozásának és múk ödtetésének költségei más európai országokhoz képest meglehetôsen magasak. Görögországban például egy új vállalat indításához 45 napra és 16 különbözố hivatalos eljárásra van szükség, amelyeknek a költségei az egy főre jutó jövedelem 69,6 százalékát teszik ki, míg ugyanehhez például Dániában mindössze négy napra és négy (díjtalanul igénybe vehetố) eljárásra van szükség.

- Korlátozott IKT-készségek. Az IKT-eszközök kezeléséhez szükséges készségek alacsony szintje miatt ebben az időszakban (1994-2000) az állampolgárok nem értek el figyelemre méltó előrehaladást vagy életminőség-javulást. Az új technológiák hasznosításához az állampolgároknak tájékoztatást kell kapniuk arról, hogyan tehetnek szert nyereségre az IKT révén, és képesnek kell lenniük az IKT-eszközök használatára, ami természetesen feltételezi azok hozzáférhetôségét mindenki számára. Az ilyen lehetőségek azonban nem álltak nyitva azok elótt, akik csak korlátozott mértékben jutottak hozzá a technológiához: meg kell szüntetni a szakadékot az internet szolgáltatásait teljes mértékben kihasználni képes csoportok és az ebból egyelôre még kirekesztett állampolgárok között.

Az Európai Bizottság „i2010” jelentése (European Commission 2007) szerint az információs társadalom Görögországban még mindig lassan fejlődik, és Görögország az EU-országok rangsorának a vége felé helyezkedik el a legtöbb indikátor tekintetében. A széles sávú hozzáférés megteremtése a legalacsonyabb szintú az EU-ban, és még a keskeny sávú kapcsolatok sem nevezhetók széles körben elterjedtnek. A szükséges inf- 
rastruktúra hiányában az interneten nyújtott szolgáltatások igénybevétele jóval az átlagos szint alatt van. Ennek megfelelóen Görögországban az IK'T használatához szükséges alapvetố és speciális készségek is alacsony szinten állnak. Az IKT fejlesztésére bejelentett kezdeményezések a szabályozás, a képzés és az infrastruktúra-fejlesztés terén egyaránt még mindig korai fázisban vannak. A siker egyik alapvetố előfeltétele a távközlési szolgáltatási piac liberalizációjának gyors véghezvitele. Ez várhatóan jelentős csökkenéshez fog vezetni a távközlési szolgáltatások átlagos költségeiben, amelyek különösen a gazdasági felhasználók esetében mindeddig igen magasak maradtak. Tovább kell fejleszteni azonban a szolgáltatások minôségét és választékát is. Az információs és kommunikációs technológiák fokozott felhasználása a közigazgatásban, az iskolákban és a munkahelyeken is nagy lehetôségeket rejt magában, ám ezek kihasználása pillanatnyilag még korlátozott mértékú.

Görögország célja az EU átlagos szintjének elérése 2009-ig (EKT 2007). Az információs társadalom fejlődésének elősegítése érdekében a hangsúly a vezeték nélküli széles sávú internet-hozzáférés elterjesztésére kerül a távoli régiókban is.

\section{Statisztikai adatok}

Az információs társadalom fejlettségének alábbi indikátorai (Eurostat 2007; Greek IS Observatory 2007b) jól megvilágítják az e-kormányzati szolgáltatások bevezetése terén Görögországban uralkodó feltételek „érettségét”:

1. táblázat

E-készenlét

\begin{tabular}{|c|c|c|c|c|c|c|}
\hline \multirow[b]{2}{*}{ Százalékos arányok } & \multicolumn{3}{|c|}{$\mathrm{EU}-25$} & \multicolumn{3}{|c|}{ Görögország } \\
\hline & $\begin{array}{l}2004 . \\
\text { július }\end{array}$ & 2005 & 2006 & $\begin{array}{l}2004 . \\
\text { július }\end{array}$ & 2005 & 2006 \\
\hline - számítógéppel felszerelt háztartások & 54 & 58 & 62 & 29 & 33 & 37 \\
\hline $\begin{array}{l}\text { - otthoni internet-hozzáféréssel } \\
\text { rendelkezó háztartások }\end{array}$ & 42 & 48 & 51 & 17 & 22 & 23 \\
\hline - számítógépet használó vállalkozások & 95 & 96 & 97 & 95 & 98 & 97 \\
\hline $\begin{array}{l}\text { - internet-hozzáféréssel rendelkezó } \\
\text { vállalkozások }\end{array}$ & 89 & 91 & 93 & 87 & 92 & 94 \\
\hline $\begin{array}{l}\text { - széles sávú kapcsolattal bíró } \\
\text { háztartások }\end{array}$ & 6.5 & 17 & 26 & 0,2 & 1 & 4 \\
\hline - széles sávú kapcsolattal bíró vállalkozások & 43 & 54 & 67 & 16 & 39 & 53 \\
\hline $\begin{array}{l}\text { - az internetet hetenként legalább } \\
\text { egyszer használó egyének }\end{array}$ & 38 & 43 & 47 & 17 & 18 & 23 \\
\hline $\begin{array}{l}\text {-az utóbbi három hónap során online vásár- } \\
\text { lást vagy megrendelést lebonyolító egyének }\end{array}$ & 16 & 18 & 21 & 1 & 2 & 3 \\
\hline $\begin{array}{l}\text { - az elöző́ év során online megrendeléseket } \\
\text { fogadó vállalkozások }\end{array}$ & 14 & 12 & 15 & 6 & 7 & 7 \\
\hline \multicolumn{7}{|l|}{$\begin{array}{l}\text { - az internetet közigazgatási szervekkel való } \\
\text { interakcióra felhasználó egyének }\end{array}$} \\
\hline információszerzés & 21,4 & 20,7 & 22,6 & 7,2 & 4,7 & 5,5 \\
\hline úrlapok letöltése & 9,8 & 10,5 & 14,1 & 2,8 & 1,8 & 0,9 \\
\hline kitöltött úrlapok visszajuttatása & 5,6 & 6,1 & 9,3 & 2,4 & 3,2 & 2,1 \\
\hline
\end{tabular}


1. táblázat (folytatás)

\begin{tabular}{||c|c|c|c|c|c|c||}
\hline \multirow{2}{*}{ Százalékos arányok } & \multicolumn{3}{|c|}{ EU-25 } & \multicolumn{3}{c|}{ Görögország } \\
\cline { 2 - 7 } & $\begin{array}{c}2004 . \\
\text { július }\end{array}$ & 2005 & 2006 & $\begin{array}{c}2004 . \\
\text { július }\end{array}$ & 2005 & 2006 \\
\hline $\begin{array}{l}\text { - az internetet közigazgatási szervekkel való } \\
\text { interakcióra felhasználó vállalkozások }\end{array}$ & & & & & & \\
\hline $\begin{array}{l}\text { információszerzés } \\
\text { úrlapok letöltése }\end{array}$ & 45 & 51 & 55 & 61 & 72 & 71 \\
\hline kitöltött úrlapok visszajuttatása & 29 & 39 & 56 & 58 & 69 & 67 \\
\hline
\end{tabular}

2006-ban a görög háztartások 37 százalékában volt számítógép, míg ugyanez az arány az Európai Unió korábbi 15 tagországában 64\%, a 25 tagállam átlagában pedig 62\% volt. Hasonlóképpen, az internetfelhasználók összesen 23 százalékot tettek ki a görög háztartásokban, összehasonlítva az EU korábbi 15 tagállamának 52 százalékos, illetve az EU-25-ök 51 százalékos átlagával (Eurostat 2007). Mint a fenti adatokból látható, a görög háztartások az IKT-eszközökhöz való hozzáférés és az eszközök használata terén egyaránt nagy lemaradásban vannak.

\section{E-készségek}

Az IKT felhasználásához szükséges készségek megléte globális szinten is döntő fontosságú nemcsak az IKT-iparágak, hanem az egész társadalom és a gazdaság szempontjából. Ahhoz, hogy a vállalatok és az intézmények vállalkozhassanak az új technológiák bevezetésére, valamennyi szektorban megkerülhetetlen követelmény a megfelelô készségekkel rendelkezố munkaerố foglalkoztatása. Az utóbbi évtizedben az IKT alkalmazásában jártas munkavállalók aránya egyenletesen emelkedett. A modern gazdaságokban az összes foglalkoztatott körülbelül 20 százalékáról mondható el, hogy birtokában van az IK'T alkalmazásához szükséges alapvetô készségeknek (HLG 2006b). Egy megjelenés eloótt álló tanulmány szerint, amely az Eurostat adataira támaszkodik, a görög lakosság 37 százaléka semmiféle számítógép-használati készséggel nem rendelkezik, és csupán 22\% túnik tájékozottnak a számítógépes tevékenységek szélesebb spektrumában (DeMunter 2006). A 2. táblázat néhány e-készség összehasonlító értékeit mutatja Görögország és az EU-25 viszonylatában.

2. táblázat

E-készségek

\begin{tabular}{|l|c|c|c|c||}
\hline & \multicolumn{2}{|c|}{ EU-25 } & \multicolumn{2}{c||}{ Görögország } \\
\hline \hline Azoknak az egyéneknek a százalékos aránya, akik & 2005 & 2006 & 2005 & 2006 \\
\hline • már másoltak vagy áthelyeztek fájlokat vagy könyvtárakat & 53 & 55 & 28 & 43 \\
\hline • használtak keresốprogramot & 51 & 54 & 25 & 35 \\
\hline - küldtek melléklettel ellátott -mail üzenetet & 43 & 45 & 18 & 22 \\
\hline - írtak üzeneteket csevegófórumokba, hírcsoportokba & 18 & 19 & 5 & 9 \\
\hline vagy más online fórumokba & 7 & 9 & 2 & 4 \\
\hline - használtak internetes telefonszolgáltatást & 9 & 9 & 2 & 4 \\
\hline - létrehoztak hálózati honlapot & 9 & 9 & 3 & 6 \\
\hline • írtak programot valamilyen programozási nyelven & & & & \\
\hline
\end{tabular}


A 3, táblázat az e-készségek szokásos megszerzési módját mutatja be. Az információs társadalom kiépítésének egyik szélesebb kört érintố célja annak a lehetôvé tétele, hogy az e-készségek nemcsak a formális oktatás keretei között, hanem személyes tanulmányok és tudásmegosztás útján is megszerezhetók legyenek (Zambarloukos-Constantelou 2002).

3. táblázat

Az e-készségek megszerzésének módja

\begin{tabular}{|l|c|c|c|c||}
\hline & \multicolumn{2}{|c|}{ EU-25 } & \multicolumn{2}{c|}{ Görögország } \\
\hline $\begin{array}{l}\text { Azoknak az egyéneknek a százalékos aránya, } \\
\text { akik e-készségeiket az alábbi módokon szerezték }\end{array}$ & 2005 & 2006 & 2005 & 2006 \\
\hline - formális oktatási intézményekben & 20 & 21 & 14 & 17 \\
\hline - felnốtképzési központokban & 10 & 11 & 9 & 12 \\
\hline $\begin{array}{l}\text { - személyre szabott tanulmányok, könyvek, } \\
\text { CD-ROM stb. felhasználásával }\end{array}$ & 20 & 25 & 5 & 8 \\
\hline - önálló tanulmányok útján & 41 & 41 & 17 & 29 \\
\hline - barátok, rokonok stb. közremúködésével & 41 & 39 & 15 & 23 \\
\hline
\end{tabular}

Az Economist Intelligence Unit (EIU 2007) által az e-készenlétre vonatkozóan készített rangsorban Görögország 2007-ben 69 ország közül a 32. helyre került 6,31 pontértékkel a 10-es skálán (ugyanez az érték 2006-ban 6,42 volt). A 4. táblázat az egyes kategóriákban szerzett pontszámokat és a kategória súlyozását mutatja be, összehasonlításul Görögország mellett a listavezetố Dánia pontértékeit is feltüntetve.

4. táblázat

Az e-készenlét mértéke a: Economist Intelligence Unit kimutatása szerint (EIU 2007)

\begin{tabular}{|l|c|c|c|c|c|c|c||}
\hline & $\begin{array}{c}\text { Összesített } \\
\text { pontszám }\end{array}$ & $\begin{array}{c}\text { Konnek- } \\
\text { tivitás és } \\
\text { technológiai } \\
\text { infrastruk- } \\
\text { túra }\end{array}$ & $\begin{array}{c}\text { Üzleti } \\
\text { környezet }\end{array}$ & $\begin{array}{c}\text { Társadalmi } \\
\text { és kulturális } \\
\text { környezet }\end{array}$ & $\begin{array}{c}\text { Jogi } \\
\text { környezet }\end{array}$ & $\begin{array}{c}\text { A kormány } \\
\text { politikája } \\
\text { és jövóképe }\end{array}$ & $\begin{array}{c}\text { A fogyasztói } \\
\text { és vállalati } \\
\text { alkalmazá- } \\
\text { sok }\end{array}$ \\
\hline Kategória súlya & $20 \%$ & $15 \%$ & $15 \%$ & $10 \%$ & $15 \%$ & $25 \%$ \\
\hline Görögország & 6,31 & 4,70 & 6,68 & 6,60 & 7,95 & 6,90 & 6,20 \\
\hline Dánia & 8,88 & 8,40 & 8,65 & 8,60 & 8,50 & 9,85 & 9,15 \\
\hline
\end{tabular}

Az egyes kategóriákban szereplő pontszámokból láthatjuk, hogy a „konnektivitás és technológiai infrastruktúra”, , a kormány politikája és jövóképe”, ,, a fogyasztói és vállalati alkalmazások" kategóriákra vonatkozó pontszámok Görögországban - Dánia megfeleló értékeihez képest - különösen alacsonyak.

\section{Politikai törekvések}

Az előzőekben közölt európai adatok fényében megállapítható, hogy Görögország még mindig lemarad az EU más tagállamai mögött.

Az információs technológiák stratégiai tervezéséért és fejlesztéséért felelős legmagasabb szintú görög állami intézmény, az Információs Technológiai Bizottság 2005ben elfogadta a 2006-2013 közötti idószakra kidolgozott integrált digitális stratégiát, 
amely - a „digitális ugrás a termelékenységben - digitális ugrás az életminôségben” jelszavával - világos jövóképet állít a társadalom elé (Greek Digital Strategy 2006).

Az „i2010” stratégia egyik fó célja az „e-befogadás” ( $\ell$-Inclusion), amelynek jegyében az IKT felhasználásával elősegíthetók a kirekesztéssel fenyegetett társadalmi csoportok beilleszkedésére irányuló erófeszítések. A cél annak a megakadályozása, hogy a már bevezetett és a jövóbeli innovációk következtében új szakadék jöjjön létre a digitális kultúra tekintetében „gazdag”, illetve „szegény” rétegek között ( $E U$ Info Sheet 7.3 2006). Görögországban az országos hatókörú demokratikus tervezési hálózat (National Network on Design for All, lásd GR-DeAN 2003) részt vesz a mindenki számára e-hozzáférést nyújtó európai hálózat (European Design for All e-Accessibility Network, EDeAN) megtervezésében, hozzájárulva ezáltal az e-hozzáférhetôség fokozására irányuló akcióterv (e-Accessibility Action Plan) célpontjainak meghatározásához és az Európai Bizottság által elfogadott eEurope kezdeményezés célkitúzéseinek megvalósításához. Elősegíti az „egyetemes hozzáférés” (Universal Access) és a „demokratikus tervezés” (Design for All) elveinek széles körü alkalmazását, valamint a fogyatékkal élók egyenlő részvételét a görög információs társadalomban. „Az információs társadalom operatív programja” (Operational Program for the Information Society, OPIS) keretében egy szponzorált hálózati portálon öt különböző szakmai csoport (Special Interest Group, SIG) támogatja és ösztönzi a vitákat, az információcserét és az eszmék szabad áramlását a hálózati közösségek tagjai, az Európai Bizottság és az e-hozzáféréssel foglalkozó szakértôi csoport (e-Accessibility Expert Group) között.

\section{Digitális stratégia 2006-2013}

Az Európai Unió tagállamai az e-kormányzati célok elfogadásával kötelezettséget vállaltak annak biztosítására, hogy 2010-ig valamennyi állampolgár - beleértve a társadalmilag hátrányos helyzetú csoportok tagjait is - az e-kormányzati szolgáltatások haszonélvezójévé válhat. A tagállamok egyik fontos feladata gondoskodni arról, hogy a közérdekú információk és szolgáltatások az IKT innovatív felhasználása, a fejlettebb alkalmazási készségek kialakítása és az állami támogatások révén valamennyi állampolgár számára könnyen hozzáférhetók legyenek. Biztosítani kell továbbá az e-kormányzati szolgáltatások hasznosságának fokozott tudatosítását és a közvélemény bizalmát ezek iránt. Az e-kormányzatnak el kell érnie egy olyan fejlettségi szintet, amely az európai állampolgárok és vállalkozók számára lehetôséget ad arra, hogy az interoperábilis elektronikus identitásmenedzsment (Interoperable Electronic Identity Management, eIDM) rendszer haszonélvezôi legyenek. Az eIDM rendszer felhasználható a közszolgáltatások igénybevétele, az elektronikus dokumentumok hitelesítése és az elektronikus archiválás terén egyaránt. Hozzátartozik a digitális aláírás használata az online közszolgáltatások biztonságos módon való igénybevételére. Bevezetése - eleget téve a szolgáltatási igények, a kulturális hagyományok és a személyes adatvédelem követelményeinek - az EU több tagállamában már folyamatban van. Az eIDM rendszer múködése gyakorlatilag annyit jelent, hogy ha egy állampolgár emigrálni kíván, vagy egy vállalat az Európai Unió egy másik tagállamába kíván áttelepülni, akkor is részesülhessen a közszolgáltatásokban, például egészségügyi ellátást kapjon, és elektronikus úton szavazhasson sze- 
mélyes adatainak garantált védelme mellett (SCP-5, 2007). Az Európai Bizottság pragmatikus szemlélettel kívánja megvalósítani a különböző $e I D M$ rendszerek interoperabilitását. A kitűzött cél a megfelelő közszolgáltatások azonosításának és igénybevételének lehetővé tétele bármelyik tagországban, tiszteletben tartva az eltérô nemzeti megoldásokat, ám egyszersmind mentesítve a közszolgáltatások igénybevétele elôtt álló akadályoktól az országhatárokat.

A 2006-2013 közötti idôszakra kidolgozott digitális stratégia életbelépése hatályon kívül helyezte a „Görögország az információs társadalomban” címú, 1999 februárjában bevezetett és 2002-ben megújított kormányprogram e-kormányzati stratégiáját, és a korábban kitúzött célok felülvizsgálata nyomán az információs társadalom jelenleg érvényben levó európai operatív programjában (Operational Program for the Information Society, OPIS) foglalt tennivalók végrehajtását helyezte a középpontba (Infosoc 2007).

A 2006-2013 közötti digitális stratégia célja a Görögországot más tagállamoktól még mindig elválasztó digitális szakadék áthidalása. A dokumentum kiemeli, hogy az IKT fokozott felhasználása eloosegíti a gazdaságban a nagyobb termelékenység elérését, és fontos szerepet játszik az állampolgárok életminôségének javításában. Az alapvetô különbség a korábbi gyakorlathoz képest abban áll, hogy az új stratégia nem egyes szervezetek számára ír elő speciális programokat, hanem a szolgáltatásokra koncentrál. Fő célja valamennyi szükséges feltétel megteremtése a „digitális ugrás” megtételéhez a termelékenység és az életminôség tekintetében a 2006-tól 2013-ig terjedő idôszakban. Az új digitális stratégia az információs társadalom koherens és integrált módon történő kiépítése jegyében kíván megfelelni az úgynevezett „negyedik múveleti szakasz” (4th Operational Period, 2007-2013) kihívásainak, csatlakozva az információs társadalom operatív programjához (OPIS). A görögországi törekvések összhangban állnak az Európai Unió új „i2010” stratégiájával, valamint a „Foglalkoztatás és növekedés” európai akciótervével (Jobs and Growth Action Plan).

Az alapvetô cél, az információs és kommunikációs technológiák (IKT) felhasználásának fokozása és az ehhez szükséges új készségek fejlesztése Görögországban négy fontos elókészítố lépés megtétele alapján valósulhat meg.

1. lépés: Az IKT használatát akadályozó tényezók forrásainak azonosítása és vizsgálata Görögországban - a problémák gyökerét feltáró elemzés.

2. lépés: Az információs társadalom építése és az új technológiák alkalmazása terén érvényesülő́ nemzetközi politikai törekvések és az eddig szerzett tapasztalatok elemzése, valamint a „legjobb gyakorlatok” és a kudarcok azonosítása húsz országban.

3. lépés: Az információs társadalom építésében elért nemzetközi és európai eredmények - az EU „i2010” stratégiájának megvalósítása érdekében tett lépések, az információs társadalom kérdéseiról tartott csúcstalálkozók (WSIS) stb. - tanulmányozása.

4. lépés: Az alapvető irányelvek meghatározása a 2006-2013 közötti időszakban követendő digitális stratégiához, együttmúködve az érintett szereplókkel, és számításba véve a görög gazdaság és társadalom sajátos vonásait.

A termelékenység és az életminôség javításához vezetô digitális ugrás megtételéhez a 2006-2013 közötti időszakra kidolgozott stratégiai dokumentumok (Greek Digital Strategy 2006, Digital Strategy 2006) hat egymással összefüggő részcélkitúzést fogalmaznak meg: 


\section{A termelékenység növelése}

1. Az IKT használatának elôsegítése a vállalatoknál, az egyes cégek és ezen keresztül az egész ország termelékenységének növelése érdekében.

2. Az állami szektor átszervezése során
a. az IKT használatának fokozása a belső folyamatokban,
b. a digitális szolgáltatások fejlesztése.

3. Az IKT-profilú vállalatok támogatása a GDP-hez való hozzájárulásuk növelése céljából.

4. A vállalkozó szellem erôsítése, különös tekintettel az IKT-profilú vállalatokra és azokra a cégekre, amelyek dinamikusan használják az új technológiákat.

\section{Az életminốség javitúsa}

1. Az IK'T-eszközök dinamikus felhasználásának ösztönzése az állampolgárok mindennapi életében.

2. A bürokrácia csökkentése és az eljárások gyorsítása a digitális szolgáltatások fejlesztése révén.

Az állampolgárok életminóségére koncentrálva az információs társadalomban a következő területekre kerül a hangsúly:

- Infrastruktúra

- Széles sávú hozzáférés (a 2007. év „a széles sávú kapcsolatok éve”).

- Hozzáférhetố egy megállóhelyes üzletek kifejlesztése.

- A lakosság speciális csoportjai számára készülő IKT-berendezések pénzügyi támogatása.

- Oktatás

○ Távtanulás-távoktatás.

- Hozzáférhető oktatási tartalom kifejlesztésének ösztönzése.

- Egészségügy

- Hozzáférhetố regionális egészségügyi szolgáltatások.

- Egyetemesen hozzáférhető egészségügyi nyilvántartások és más ehhez kapcsolódó információk.

- Közigazgatás

- Hozzáférhetố e-szolgáltatások a regionális önkormányzatoknál.

- Digitális tartalom- és információszolgáltatás.

A rövid távú feladatok tekintetében a 2008 mérföldkônek számít. Több mint hatvanötféle tevékenységre vonatkozóan születtek javaslatok: valamennyinek a középpontjában az emberi eróforrások állnak. A készségek fejlesztését a tervek a képzés kiterjesztése révén célozzák meg.

A 2006-2013 közötti idốszakra kidolgozott digitális stratégián belül az egyik legkonkrétabb e-kormányzati projekt 2005 novemberében indult meg, a közigazgatás országos hálózatának (National Network of Public Administration, $\Sigma$ YZY $\Sigma \Theta H \Sigma$, SYZEFXIS) megteremtése érdekében. A SYZEFXIS a görög Belügyi, Közigazgatási és Decentralizálási Minisztérium projektje. Célja az állami szektor távközlési infrastruktúrájának korszerúsítése a belsố kommunikáció szükségleteinek kielégítésére, az állami szektor valamennyi intézménye és szervezete (kórházak, társadalombiztosítási alapok, könyv- 
tárak stb.), továbbá az országos és a helyi közigazgatási hivatalok, illetve hatóságok között kapcsolatot teremtố széles sávú hálózatok útján, valamint hozzáférés biztosítása - mindenfajta digitális kirekesztés nélkül - a közigazgatás valamennyi szolgáltatásához az állampolgárok és a vállalatok részére az interneten keresztül. 2006 júniusában a SYZEFXIS rendszer bekapcsolódott a huszonöt EU-tagállam kormányzati hivatalainak transzeurópai telematikai hálózatába (25 Trans-European Service for Telematics between Administrations, TESTA25), és állandó kapcsolatot létesített a Hellén Kutatási és Technológiai Hálózattal (GRNET). A TESTA-hálózat biztosítja az együttmúködést a tagállamok kormányzati hivatalai között mindenfajta európai e-kormányzati alkalmazás tekintetében. Ezt az erôsen védett hálózatot a nemzetbiztonsággal, különféle csalási ügyekkel, menedékjogot keresố személyekkel, nemzetközi hajózási forgalommal stb. kapcsolatos bizalmas információk cseréjére használják fel. Erre néhány példa: a CARE a baleseti statisztikai adatok, a FIUNET a pénzmosási múveletekkel kapcsolatos információk, a PROCIVNET-CESIS a természeti és technológiai katasztrófákkal sújtott állampolgárok védelmével kapcsolatos információk, a SAFESEANET pedig a környezetszennyezéssel és az ilyen következményekkel járó balesetekkel összefüggó információk cseréjére szolgál. 2007 júliusában Görögország csatlakozott a TESTA kibővített európai hálózatához (European $S$-Testa Network) is, amelynek nevében az „S” betú a biztonságra (security) utal (Syzefxis 2007, Infosoc 2007).

\section{Az információs társadalom operativ programja \\ (The Operational Programme for the Information Society, OPIS)}

Az információs táradalom operatív programjának végrehajtásához létrehozott speciális igazgatási szolgálat (Special Management Service of the Operational Programme for the Information Society) egyike a közösségek támogatására irányuló harmadik keretprogram ( $3^{\text {rd }}$ Community Support Framework 2000-2006) 25 szektorális és regionális alprogramját irányító hatóságoknak, amelyek múködését az Európai Szociális Alap (European Social Fund) és az Európai Regionális Fejlesztési Alap (European Regional Development Fund) közösen finanszírozza (Infosoc 2007).

Az OPIS mint az információs társadalom alapvetố jellemvonásainak megteremtésére irányuló horizontális innovációs program kiterjed valamennyi kormányzati intézményre, s ily módon az információs társadalomhoz vezetô általános országos stratégia megvalósításának egyik fơ támogatója. Az operatív program keretében nagyobb intézményi akciókra és ezekkel párhuzamosan kiegészítố intézkedések bevezetésére kerül sor. Létrehoztak egy hálózati honlapot az állampolgárok tájékoztatására (CSF Citizens' Online Information System, ${ }^{2}$ 2007), amely pontos és áttekinthetô információkat nyújt görög nyelven az egyéneknek (különféle pénzügyi támogatási sémákról, foglalkoztatási programokról, szociális támogatási projektekról, oktatási és képzési lehetôségekról stb.), a vállalatoknak és a vállalkozóknak (pénzügyi támogatási sémákról, szubvencionált foglalkoztatási lehetôségekról, alkalmazottaik munkahelyi továbbképzéséhez

\footnotetext{
${ }^{2}$ A közösségi támogatási keretból (Community Support Framerwork, CSF) finanszírozott projektekre vonatkozó információkat rendszeresen frissítik.
} 
igénybe vehetố programokról stb.), valamint hasonló kérdésekben más szervezeteknek és testületeknek, köztük az oktatási és kutató intézményeknek is. Ugyanitt adnak hírt továbbá a várhatóan a közeljövóben induló újabb programokról is.

A görög kormány - tekintetbe véve, hogy az információs és kommunikációs technológiák (IKT) alapvetốen fontos eszközöket nyújtanak a nyitott és hatékony kormányzás megvalósításához, valamint a szervezetek versenyképességének javításához - különös figyelmet fordít az információs társadalom fejlődésének elómozdítására. Hangsúlyt fektet az oktatási rendszernek a folyamatos tanulás szempontjából kedvezố módon történó átalakítására, hogy az alkalmas legyen a tanulók felkészítésére az új készségek és új munkamódszerek elsajátításához, s ugyanakkor a megerôsített egészségügyi, közlekedési és környezeti szolgáltatások elérhetôvé tételével jobb életminőség biztosítására törekszik. A kormányprogramokban kiemelt hangsúlyt kap a kulturális örökség és a görög nyelv védelme.

Az IKT-termékek és szolgáltatások igénybevételére irányuló belföldi kereslet azonban az állami szervek, a vállalatok és a fogyasztók részéról is mindeddig fejletlen és problematikus maradt (Greek IS Observatory 2006). Az állami szektor követelményei viszonylag alacsony szintúek, s ezeknek az érvényesítését is hátráltatja a törvényhozás rugalmatlansága és a bürokrácia. Ennek eredményeként nagy késés mutatkozik fontos állami projektek végrehajtásában. Az itt jelentkezó gondoknál is nehezebb feladatot jelent azonban az új elektronikus szolgáltatások létrehozása, és az a célkitûzés, hogy az állampolgárok és a vállalatok mind jobban megismerkedjenek az IK'T-vel, ugyanis mindenekelốtt a vállalatok, de nyomukban a fogyasztók is sokkal fontosabb IKT-piacot képeznek, mint az állami szektor.

Az információs társadalom megvalósulása felé tett haladás során Görögország számos kihívással néz szembe, amelyek közül az alábbiakban csak a legfontosabbakat említjük meg (Greek Observatory ${ }^{3}$ 2006, 2007; Greek Digital Strategy 2006; EKT 2007).

\section{A népesség korlátozott IKT-készségei:}

- A munkaerố csekély hányada rendelkezik a szükséges IKT-készségekkel.

- Hiányoznak az átképzés és az egész életen át tartó tanulás ösztönzô eszközei.

- Az oktatási infrastruktúra nagyarányú fejlesztésére van szükség az oktatás valamennyi szintjén.

2. Az IKT használatából származó elő́nyökkel kapcsolatos tájékozottság hiánya: a fogyasztók és a vállalatok jelentôs hányada nincs meggyốzôdve az IKT-be való befektetés érezhetố hasznosságáról.

3. Technofóbia: a szolgáltatások és a felszerelések gyenge múködéséból adódó ellenérzésekból fakadóan a közigazgatásban hiányzik a technológiai kultúra.

4. Ellenállás nyilvánul meg a szükséges szervezeti változásokkal szemben.

5. A távközlési szolgáltatások a széles sávú hozzáférés magas költségei miatt lassan fejlốdnek.

Agrafiotis (1997) odáig megy, hogy azt állítja, a görög társadalom esetében bizonyos feltételek és körülmények nincsenek meg, s ennélfogva az információs társadalom

\footnotetext{
${ }^{3}$ A görög információs társadalom fejlődését illetően kulcsfontosságú tájékozódási forrást nyújt az Observatory for the Greek Information Society, amelynek elektronikus adatbankja és archívuma pontos és naprakész információkat tartalmaz a görög és külföldi intézmények ez irányú felméréseinek eredményeiról.
} 
kifejezés használata nem indokolt, noha a technika és a tudomány, valamint a politika, a kulturális tanulmányok, az újságírás és a közéleti viták kontextusában gyakran elófordul. Kétségtelen, hogy ez a kifejezés tudományos nézópontból találónak és relevánsnak túnik, és elfogadható a modern társadalompolitika szociokulturális perspektívájából is. Az információs társadalom építése azonban nemcsak tudományos szempontból érdekes, hanem azonnali gyakorlati válaszokat követeló kérdéseket is felvet. A szervezett közösségi akciók sikeréhez fogalmi pontosságra és az alkalmazott kifejezés társadalmi elfogadottságának tanulmányozására van szükség. A társadalom szempontjából (szociokulturális és politikai téren egyaránt) maguknak az információs és telekommunikációs technológiáknak a görögországi helyzete határozza meg azoknak az akadályoknak a természetét, amelyek nem engedik meg az információs társadalom kifejezés alkalmazását a görög társadalomra. Sürgősen el kell tehát dönteni, hogy ezek közül az akadályok közül melyek szüntethetók meg, és ez milyen mechanizmusok felhasználásával, illetve mely társadalmi szereplók közremúködésével érhetố el. Ugyanilyen fontos annak a meghatározása is, hogy a görög társadalom mely szociokulturális és politikai sajátosságai teszik lehetôvé a különféle gazdasági szereplók és társadalmi csoportok számára, hogy megalapozzák jelenlétüket a globalizálódó világban.

A megoldandó problémák sokasága dacára is közmegegyezés van abban a tekintetben, hogy az IKT fokozott felhasználása lehetôséget nyújt a jelenlegi gyengeségek leküzdésére. Görögországban megvan a lehetôség a kisebb mértékú fejlesztésekre is. A hatékony ösztönzô eszközök megteremtéséhez és megfelelő szabályozási keretrendszer kialakításához új kezdeményezések koherens és rugalmas rendszerére van szükség.

A külső igények növekednek. Az IKT-profilú vállalatok exporttevékenysége mindeddig a feldolgozóiparban és a kereskedelemben múködő nagy cégekre korlátozódott. Az információs technológiai szolgáltatások terén kivételt képez ez alól néhány kisebb exportra orientált cég múködése. Vannak továbbá bizonyos jelek, amelyek a belföldi kereslet erósödésére utalnak, miközben a vállalatok igyekeznek nagyobb mértékben kihasználni a külső keresletet is. Jelentôs számú nagyvállalat és középvállalkozás alkalmaz fejlett IK'T-eszközöket és berendezéseket más fejlett országokkal összemérhetô szinten.

Ezek a vállalatok értéktermelô láncolataikban együttmúködnek számos kisebb vállalkozással is. Az utóbbiak - annak érdekében, hogy fenn tudják tartani pozíciójukat a releváns piacon, és megtarthassák nagyobb klienseiket - még akkor is rákényszerülnek a lépéstartásra, ha nincsenek teljesen meggyőzoódve az IKT terén eszközölt befektetések hasznosságáról. Ugyanakkor az IKT újabb és aktívabb felhasználói, aki ma kezdik meg gazdasági tevékenységüiket, egyenletesebbé teszik az IKT elterjedését az országban.

Az állam szerepe szintén erósödik a másodlagos kereslet megteremtésében. Az állam - tájékoztatási és képzési célú kampányai mellett - egyre több elektronikus szolgáltatást nyújt, miközben folyamatosan javítja a hivatalok múködésének hatékonyságát az új technológiák alkalmazásával. Az e-kormányzati szolgáltatások hatékonyabb ügyintézést tesznek lehetôvé: az e-kormányzati szolgáltatások megvalósítása a vállalatokkal való hatékonyabb interakciókon és az állampolgároknak nyújtott jobb szolgáltatásokon alapul. Az innovatív megoldások kihasználják az együttmúködő környezetet az új szolgáltatások megteremtésére, és összekötik egymással az állami és a magánszektort. Ezek a szolgáltatások költséghatékonyságot, termelékenységnövekedést és általános hatékonyságot biztosítanak felhasználóiknak. Emellett politikai szinten is szaporodnak az információs társa- 
dalommal közvetlenül vagy közvetve összefüggó kezdeményezések és akciók, bár ezek többnyire kiegészítố elemként épülnek be az egyes szakpolitikai területeken, pl. az oktatás, a foglalkoztatás, a beruházások stb. terén tett erốfeszítésekbe.

A kínálati oldalon végbemenô változások szétszórtak, kisméretúek, és igen sok vállalat között oszlanak meg. Úgy túnik, hogy hiányoznak a szisztematikus törekvések a tanulás és a piac specializálódására. A már megalapozott vállalkozói kultúra hiányát maga az a tény magyarázhatja, hogy az IKT-szektor viszonylag új, és egy olyan üzleti szférához tartozik, amelyet az igen gyors technológiai fejlődés jellemez. Intenzív árverseny folyik, de valamennyi cég hasonló termékeket vagy szolgáltatásokat kínál, amelyek között nincsenek lényegi különbségek. Noha igaz, hogy ez a szektor kétségkívül innovatívként jellemezhetô, a görög vállalatoknál a kutatás és fejlesztés igen ritka jelenség, és csupán kevés cégre korlátozódik. Ezek azonban többnyire érdekes, kiterjedt és fontos kutatási programok részvevóiként rendszeresen együttmúködnek az egyetemekkel.

Az európai információs társadalom megteremtésének általános stratégiáján belül Görögország információs társadalmi stratégiája - a maga speciális céljainak és sajátos körülményeinek megfelelốen - az alábbi alapelvekre épül:

- Innováció és vállalkozó szellem. Az információs táradalom a piaci mechanizmusok alapján fejlődik, és a szabályozási kereteknek elő kell segíteniük az új üzleti kezdeményezéseket és az innovációt.

- Demokrácia és személyi szabadságjogok. Az információs társadalomnak ki kell bóvítenie a demokratikus folyamatokat, és védenie kell az állampolgárok jogait.

- Egyenlö lehetóségek és társadalmi kohézió. Az információs társadalomnak valamennyi állampolgár számára biztosítania kell az új technológiák által elérhetôvé tett lehetôségekhez, tudáshoz és piacokhoz való hozzáférést.

Az OPIS a 2000-2006 közötti időszakra két általános stratégiai célt tûzött ki:

Az első általános cél az „Állampolgárok és életminôség” címet viseli. Ez az átlagos állampolgárok életminóségének javítására utal olyan kritikus fontosságú területeken végrehajtandó akciók révén, mint a közigazgatás, az egészségügy, a közlekedés és a környezetvédelem. A fố cél az integrált információs és kommunikációs rendszerek révén „valós idôben” igénybe vehetố közigazgatási szolgáltatások megteremtése.

A második cél megnevezése („Gazdasági fejlődés és emberi erooforrások”) a gazdasági és társadalmi fejlődési folyamat kibontakozásához megfelelő feltételek megteremtésére utal, amelyek lehetốvé teszik, hogy a jövedelmek, a foglalkoztatottság és a képzettségi szint növelésének, valamint a termelékenység és a versenyképesség javításának két legfóbb eszköze a technológia és a tudás legyen. Ez megkívánja a 21. század igényeihez alkalmazkodó oktatási és képzési rendszer kialakítását olyan gazdasági mechanizmusok és foglalkoztatási rendszer támogatásával, amely - a görög kultúra értékeinek ápolása mellett - a legtöbbet képes kihozni az új technológiák és a távközlési infrastruktúra fejlesztéséból.

\section{Jövóbeli trendek}

Az Európai Unióban elsőrendû prioritást kap az innováció. Az IKT-t széles körben elismerik kulcsfontosságú tényezóként az innováció megvalósításában. Ezt a célt egy átfogó politikai program támogatja. A politikai döntéshozóknak azonban meg kell érte- 
niük, hogy az új gazdasági és társadalmi fejlemények egyre újabb és újabb csoportokra is kiterjesztik az információs társadalom „áldásait”, fokozva a versenyt és egyidejúleg potenciálisan erősítve Európa ipari vezetô szerepét (COM 146, 2007). Az „i2010” stratégia középtávú felülvizsgálatakor 2008-ban a következő kérdésekkel célszerú foglalkozni:

1. Hálózati innováció. A napjainkban érvényesülő́ technológiai trendek (igen nagy sebességư hálózatok, mindenütt jelen levố vezeték nélküli technológiák, új hálózati architektúrák és felhasználói interfészek) támogatásával az innováció új hulláma jelent meg az interneten. Ehhez tartoznak többek között a Web 2.0 körébe sorolható alkalmazások, ,a dolgok internete” (internet of things), a ,rácsok” (grids), a különféle webalapú szolgáltatások, a felhasználói tartalomszolgáltatás és a társadalmi hálózatépítés új formái. Ezek a trendek a következő hatásokkal járnak: a) az e-gazdaság új lehetôségeinek és új megoldásainak biztosításával befolyásolják a gazdasági és munkahelyi környezetet,

b) a munkával töltött élet mérlegének javításával kihatnak a foglalkoztatási szerkezet alakulására,

c) bóvítik a felhasználók szerepét, ami ki fog terjedni a tartalom létrehozására, és magában foglalja az innovációt is.

2. A felhasználók növekvó szerepe az innovációban. A felhasználók az IKT-eszközök segítségével innovatív módokon képesek saját maguk által fejlesztett tartalmakat közreadni és megosztani egymással. A 2008. évi e-Inclusion kezdeményezés jegyében az 12010 stratégia fókuszába kerültek a felhasználók, és a fogyasztók érdekei máris jelen vannak a bizottság IKT-politikájában. A politikai döntéshozók elő́tt álló kihívások magukban foglalják többek között a szerződéses kapcsolatok és az árképzés átláthatósága, a magánélet védelme és az interoperabilitás terén, valamint az alkalmazások egyre bonyolultabbá válása és a peres ügyek kevéssé hatékony elintézése következtében jelentkező feladatok megoldását.

3. A keretfeltételek javitása. Az i2010 stratégia egyik fó célja az „egységes információs tér" létrehozása. A hangsúly eddig a hálózatokra és a tartalom szabályozására esett. Az Európai Unió még mindig messze van az egységes információs tér megvalósulásától. A tagországokban sok fogyasztó kerüli, hogy az internet útján valamely másik tagországból vásároljon árukat és szolgáltatásokat. A jogi megfontolások és a szabályozási korlátok még mindig akadályozzák a vállalatok bekapcsolódását az e-gazdasági tevékenységekbe.

\section{Elektronikus közigazgatás}

Az ENSZ egyik munkacsoportja (Tsekos 2001) kidolgozott egy általános modellt a stratégiai tervezési projektekhez. Ez az általános adatmodell a stratégiakészítés és a stratégiai tervezés folyamatait írja le a közigazgatás terén két egymást kiegészítô irányzat alapján:

1. A fóbb folyamatok felülról irányított dokumentálása magas szintû́ adatmodellek hasznosításával.

2. A javasolt adat-és folyamatmodellek alulról kezdeményezett tesztelése és hitelesítése terepkutatásokból származó valós adatok felhasználásával. 
A különböző közigazgatási rendszerekre való alkalmazhatóság érdekében könnyen testre szabható modellt valamennyi tagállam rendelkezésére bocsátották.

Az OPIS második prioritási tengelyén a közigazgatási szolgáltatások és az életminôség javítása szerepel. Itt a cél az állampolgárok és a vállalatok magas színvonalú, kellố idốben és a lehető legalacsonyabb költséggel igénybe vehető szolgáltatásokkal való ellátása mind regionális, mind helyi szinteken. Ezen a kereten belül többféle kiemelt területre kerülhet a hangsúly.

E-kormányzat: gazdasági tervezés, tanulmányok és kísérleti projektek:

- A közigazgatási hivatalok felkészítése és múködésük koordinálása.

- Az IKT felhasználásával összefüggó kísérleti alkalmazások fejlesztése az állampolgárok és vállalatok számára nyújtott közigazgatási szolgáltatások minôségének javítása érdekében.

- A prototípusok tesztelése után gyakorlati megoldások bevezetése a kísérleti tapasztalatok alapján.

Regionális földrajzi információs rendszerek és innovatí akciók: stratégiák és akciótervek kidolgozása az információs társadalom építéséhez valamennyi régióban:

- Az információs társadalom fejlódésével összefüggó innovatív kísérletek ösztönzése regionális és helyi szinteken.

- Földrajzi és környezeti térképek kidolgozása állami támogatással.

- Az közigazgatási rendszerek kialakítása és azok múködésének támogatása központi, regionális és helyi szinteken.

- A modern földhivatali nyilvántartási és szabályozási keretrendszer múködtetéséhez szükséges adatbázisok és információs technológiai infrastruktúra kiépítése.

IKT-alkalmazások az egészségügyi ellátásban és a jóléti juttatásokban

- Az egészségügyi ellátás minőségének széles körű stratégiai fejlesztése.

- Az állampolgárok által igénybe vehetô szolgáltatások magasabb szintre emelése.

- Az adminisztráció és a pénzügyi gazdálkodás átszervezése az egészségügyi szektorban.

- Teljesen újjászervezett egészségügyi és jóléti rendszer létrehozása a modern IK'T felhasználásával.

- „Intelligens” közlekedés:

- Az utazással töltött idő lerövidítése.

- A kieső munkaidő csökkentése.

- A környezetszennyezés csökkentése.

- A közlekedésbiztonság javítása.

- Képzés és modernizáció a közigazgatásban:

- Azállami szektorban foglalkoztatott köztisztviselók képzése és továbbképzése.

- Modern, automatizált irodai berendezések és távközlési rendszerek alkalmazása.

A görög állampolgárok számára nyújtott e-kormányzati szolgáltatásokat általában nem megfelelőnek tartják, mert számuk csekély, és csak korlátozott interakciós lehetốségeket nyújtanak. Többségük egyszerú információs portál, amely egyes esetekben csupán az állampolgárok által letölthetô és az illetékes helyi hivatalokhoz hagyományos módon beadható formanyomtatványokat tartalmazza. A legfontosabb ilyen portál a gö- 
rög Pénzügyi és Gazdasági Minisztérium (MEF) adóhivatalának honlapja, amely lehetôvé teszi az adóbevallások és az általános forgalmi adó visszatérítésére vonatkozó, négyhavonta esedékes igények online beküldését az érintett személyek és vállalatok számára. Az adózással kapcsolatos e-szolgáltatásokat (TAXISnet $)^{4}$ a MEF égisze alatt vezették be. Az IKT felhasználásának operatív tervezéséért, bevezetéséért és fejlesztéséért az Információs Rendszerek Fótitkársága felelős. További fontos e-kormányzati szolgáltatások érhetók el más hivatalos kormányzati portálokon is, amelyek online lehetốséget nyújtanak az állampolgárok számára többek között azoknak a választói körzeteknek a megtalálására, amelyekben regisztrálva vannak (ez különösen az országos választások elótt fontos), betölthetó állások keresésére, országos könyvtárakban való kutatásra és különféle szolgáltatások igénybevételére (ilyen például az Oktatás- és Vallásügyi Minisztérium által szervezett vizsgákra való jelentkezés).

Az ENSZ Theszaloníkiben múködő közszolgálati szakmai központjának (United Nations Thessaloniki Centre for Public Service Professionalism, UNTC) jelentése szerint (Boufeas et al. 2004) a görög közigazgatásban az alábbi fóbb vonások hátráltatják az e-kormányzati szolgáltatások megvalósítását:

1. A sokszintû hierarchia és a bürokratikus szerveződés miatt az adminisztrációs mechanizmusok kevéssé hatékonyan múködnek.

2. Az integrált információs rendszereket az egyes szervezetek speciális igényeinek megfelelően külön-külön fejlesztik, s így a kommunikáció és az adatcsere tekintetében hiányzik az interoperabilitás a sok helyi hivatal között.

3. A közigazgatás meglevő technikai infrastruktúrája nem kielégítő, mivel az IKT-eszközök és -alkalmazások fejlesztése érdekében mindeddig kevés beruházás történt.

4. A köztisztviselók széles körében nincsenek meg az IK'T-eszközök felhasználásához szükséges ismeretek és készségek. A megfelelốen képzett személyi állomány hiánya miatt az intézmények gyakran csak korlátozott mértékben képesek múködtetni az információs rendszereket.

A fenti fogyatékosságokhoz hozzájárul az a tény is, hogy az állampolgároknak nincs olyan egyedi személyazonosítási számuk, mint például a svéd állampolgárok személyazonossági száma, amely tartalmazza a születési évet, hónapot és napot, valamint négy további számjegyet bizonyos információk kódolására. A svéd állampolgárok a születésükkor kapják meg személyazonossági számukat, és Svédországon belül ezt használják fel minden ügyintézésnél. A számok sorrendje a születési dátumban biztosítja az adatok könnyú szortírozását. Ugyanakkor Görögországban az állampolgárok különbözó azonosító számokat kapnak az adataikat nyilvántartó hatóságoktól (például rendôrségi ID, adózási ID, beiskolázási ID stb.), amelyek egy-egy személy azonosításához az illető nevén kívül gyakran felhasználják a szülei vagy a házastársa nevét is.

Az e-kormányzat sikeres megvalósításához Görögországban mindezeket a kedvező́tlen vonásokat meg kell változtatni, és megoldást kell találni a hiányosságok pótlására.

${ }^{4}$ A TAXISnet bevezetése egyike volt annak a 44 projektnek (összesen 281 közül), amelyek az Európai Unió „A politikától a gyakorlatig” (From Policy to Practice) címmel 2001 novemberében tartott konferenciáján megkapták a „legjobb gyakorlatoknak” járó különdíjat. Lásd www.gsis.gov.gr/home.html 
Pillanatnyilag jelentôs igény van az e-kormányzati szolgáltatásokra: az állampolgárok készek az e-kormányzati ügyintézési lehetôségek igénybevételére, mivel elégedetlenek a szolgáltatások jelenlegi helyzetével, amelyet hosszú sorban állások, késedelmek és bürokratikus eljárások jellemeznek. Jelenleg azonban igen kevés szolgáltatás vehetô igénybe az interneten keresztül. Az adóügyek (jövedelembevallások és hozzáadottérték-adó visszaigénylései) elektronikus úton történô intézésére létrehozott TAXISnet hálózattól eltekintve pillanatnyilag (2008-ban) semmi más fontosabb szolgáltatás nem áll a nagyközönség rendelkezésére. Ugyanakkor a hivatali eljárások korszerúsítésére indított, jelenleg is folyamatban levô országos program az állami szektor valamennyi intézményére kiterjed, és 2007 óta már negyvenféle kisebb jelentôségú e-kormányzati szolgáltatás vált hozzáférhetôvé az állampolgárok és a vállalatok számára (EKT 2007). Kifejlesztettek továbbá néhány e-kormányzati hálózati portált, amelyek fóleg dokumentumletöltési lehetőségeket kínálnak, de nem nyújtanak további szolgáltatásokat (European Commission 2007). Fontos fejleményt jelent a görög Belügyi, Közigazgatási és Decentralizálási Minisztérium kezdeményezése az úgynevezett „állampolgári szolgáltatási központok" (KEP) létrehozására. Ezekben a központokban az állampolgárok hozzájutnak a közszolgáltatásokra vonatkozó információkhoz, és lebonyolíthatnak számos szabványosított adminisztratív eljárást. A szolgáltatást kiegészíti a négyjegyư, 1564-es hívószámon elérhetô huszonnégy órás ügyfélszolgálat az ügyintézéssel kapcsolatos információk beszerzésére, valamint egy telefonos kérvényezési rendszer (elérhetố a 1502-es hívószámon), amelyen keresztül az állampolgárok hatvan különféle igazolást és egyéb okiratot igényelhetnek (Cap Gemini 2006).

\section{Az információs társadalom és a gazdaság}

Görögország teljesítménye a gazdasági növekedés tekintetében az elmúlt évtized során a legjobbak között volt az OECD-országok körében (OECD 2007). Különösen bátorító, hogy a növekedést az utóbbi két év során a költségvetés jelentős mértékú konszolidációja mellett is sikerült fenntartani, ami elsôsorban a beruházásoknak és az exporttevékenységnek köszönhetố. Ahhoz azonban, hogy a jó teljesítmény a jövóben is fenntartható legyen, komoly reformokra van szükség.

A növekedés számbavételére szolgáló modellek használatával nyert empirikus adatok bizonyítják, hogy az IKT felhasználása összefügg a termelékenységgel. Ezeknek a modelleknek a segítségével mérhetók a rövid távú hatások is. Beroggi és munkatársai (2005) új konceptuális módszert îrnak le azoknak az indikátoroknak a meghatározására, amelyek felhasználhatók az IKT társadalomra és gazdaságra gyakorolt hatásainak mérésére. Az erre alkalmas statisztikai mutatókat induktív úton, bizonyos hipotézisekból kiindulva határozzák meg, a politikai döntéshozókat és az IKT felhasználóit helyezve a modell középpontjába.

Az IKT-nek a termelékenységre gyakorolt hatása (az IKT-szektorban bekövetkezett hatékonyságnövekedés, valamint az IKT terén eszközölt befektetések tekintetében) az utóbbi tíz év során az Európai Unióban következetesen csupán a fele volt annak, ami az USA-ban volt tapasztalható. Az IK'T részaránya a termelékenység évi növekedésében 1995 és 1999 között az Európai Unióban 0,9 százalékot tett ki, míg az 
USA-ban 1,7 százalékos volt, majd a 2000-tól 2004-ig terjedô időszakban Európában 0,5 százalékra, az USA-ban pedig 0,9 százalékra csökkent (EU Info Sheet $7 a$ 2006).

$\mathrm{Az}$ OPIS harmadik prioritási tengelye a megfelelő feltételek megteremtését irányozza elő Görögország zökkenốmentes átmenetéhez a posztindusztriális digitális gazdaságba, amelynek alapját a tudás és az információ létrehozása, terjesztése és felhasználása képezi. Az átmenet megvalósításához kidolgozott stratégia a következő lépéseket tartalmazza:

- A megfelelő intézményi és gazdasági környezet megteremtése az ország problémamentes beilleszkedéséhez az új, digitális globális gazdaságba.

- A görög vállalatok megerôsítése az információs társadalomba való integrálódásuk érdekében:

- Az IKT használatának szorgalmazása a vállalatoknál (különös tekintettel a kisés középvállalatokra).

- Az új technológiákra alapozott vállalatok sikeres múködéséhez szükséges feltételek megteremtése.

- A vállalkozói szellem ösztönzése.

- A kutatási és technológiafejlesztési tevékenység támogatása.

- Az IKT területén elért kutatási eredmények közzététele és hasznosítása.

- A hálózatok és a fejlett telematikai szolgáltatások fejlesztése és bővítése.

- Az új környezetben és új feltételek között végzendő munkához szükséges készségek kialakítása a munkaerô-állomány egészében.

- Az új típusú munkaformák, például a távmunka szorgalmazása.

- Az információs társadalommal összefüggố munkakörökben való foglalkoztatást elốsegító pozitív környezet létrehozása.

- Az IKT terén folyó kutatások szempontjából releváns tartalmak kidolgozása és terjesztése.

\section{A távközlés országos infrastruktúrája}

Az információs társadalom gerincét az országos távközlési infrastruktúra alkotja. Ezen a téren a legfontosabb új fejlemény, amely a kormányzatok valamennyi tevékenységi területére kihat, nem más, mint a konvergencia. A hang- és adatátviteli, mozgóképés más multimédia-szolgáltatások egységes rendszerbe tömörülése egyetlen többszörös kapacitású infrastruktúrát igényel, amely a megfelelő berendezések útján képes mindezeket bárhol és bármikor mindenki számára hozzáférhetôvé tenni: a távközlés a globalizáció egyik fó motorja és egyúttal az egyik fó árucikke (HLG 2006a). A konvergencia jelentôs változásokat hoz magával az iparágak horizontális és vertikális szerkezetében egyaránt. A hagyományosan elkülönülve egymás mellett élő iparágak versengeni kezdenek, miközben a vállalatok között új vertikális partnerkapcsolatok alakulnak ki, amelyek új üzleti modellek iránti igényeket és a vertikális integráció felé mutató trendeket hoznak létre. Az IKT-vel összefüggô szektorokban fóként az alábbi technológiai trendek játszanak szerepet a konvergencia hajtóerejeként (e-Business W@tch 2006):

- A tartalom digitalizálása, tartalommegosztás az internet közvetítésével.

- A telekommunikációs szolgáltatások hálózati alapokra helyezése, hangátviteli szolgáltatások biztosítása az interneten keresztül: 
○ a széles sávú internetkapcsolatok elérhetôvé válása Európa egész területén, a nagy értéktartalmú digitális tartalomszolgáltatás terjedése.

- A mobiltechnológiák mindenütt elérhetôvé válása és kapacitásnövekedése, a mobil- és a vezetékes hálózati szolgáltatások összekapcsolódása.

A távközlési infrastruktúra használhatósága és adatátviteli sebessége Görögországban is döntố szerepet játszik az információs társadalom fejlődésében. Hasonlóképpen fontosak a digitális információk tárolásának, átvitelének és feldolgozásának a költségei is. Az országos távközlési infrastruktúrán belül az információs társadalom attribútumait jelentố, igen változatos termékek és szolgáltatások fejlesztésére van szükség, különös tekintettel az alábbiakra:

- A távközlési hálózati infrastruktúra fejlesztése a szolgáltatások hozzáférhetővé tétele érdekében, beleértve a kistelepülések, valamint a nem városi és távoli területek ellátását is a kulcsfontosságú széles sávú szolgáltatásokkal.

- Az új telekommunikációs technológiák bevezetése az állampolgárok mindennapi életében.

- Különféle alkalmazások támogatására képes fejlett távközlési szolgáltatások megvalósítása a gazdaság és a társadalom egészére kiterjedốn.

- A postai infrastruktúra fejlesztése és modernizálása, a postahivatalok továbbfejlesztése multidimenzionális központokká.

- A Közlekedési és Kommunikációs Minisztérium, a Kommunikációs Fôtitkárság, az Országos Távközlési és Postai Bizottság és más szabályozó ügynökségek személyzetének kiképzése az élvonalbeli telekommunikációs technológiák és alkalmazások használatára.

- Az emberi eróforrások jobb hasznosítása a görög postahivatalokban, elsôsorban oktatási és folyamatos továbbképzési programok révén, a posta szervezeti struktúrájának, szemléletének és technológiai bázisának fejlesztése érdekében.

Nagyvárosi hálózatok (Metropolitan Area Networks, MAN)

A fentieken kívül a görögországi tervekben szerepel úgynevezett „nagyvárosi hálózatok” kialakítása 75 helyhatósági kerületben, vezeték nélküli hálózatok (Wireless Area Networks, WAN) létrehozása 120 vidéki helyhatóságnál és további 20 helyen az önkormányzatok és a kisebb önálló közösségek együttmúködésével, valamint 770 nyilvános, vezeték nélküli széles sávú hotspot felállítása több mint 400 szervezetnél, elsősorban a turizmus szolgálatában. A szigeteken és más távolabbi helyeken a HellasSAT múhold felhasználásával fogják biztosítani a széles sávú hozzáférést.

\section{Digitális kultúra}

Az IKT hagyományosan elkülönült piacai (az internet, a telefónia és a televíziózás) ma egyre jobban összefonódnak. Egyazon hálózati infrastruktúra képes biztosítani a multimediális formában előállított tartalom teljes spektrumának eljuttatását mind a vezetékes, mind a mobilberendezéseket alkalmazó felhasználókhoz (EU Info Sheet 7.1 2006). 2005 októberében a széles sávú penetráció aránya Európában meghaladta az Egyesült Államokét. 
A széles sávú kapcsolatok elérhetővé válása jelentős hatást gyakorol az internethasználat intenzitására, valamint az egyének és a vállalkozások számára hozzáférhetô szolgáltatások jellegére is (EU Info Sheet 7.1 2006). A széles sávú kapcsolatok megléte fokozza az internetes szolgáltatások igénybevételét: ennek a hatásnak az érvényesülése szoros összefüggésben áll a szükséges sávszélességgel. A széles sávú kapcsolattal rendelkező háztartásokban élő emberek majdnem négyszer akkora gyakorisággal veszik igénybe az úgynevezett „fejlett szolgáltatásokat”, például az internetes telefonálási (VoIP) és videokonferencia-lehetôségeket. Hasonlóképpen a széles sávú hozzáféréssel bíró vállalatok a csupán keskeny sávú összeköttetéssel rendelkezóknél majdnem háromszor gyakrabban használnak komplex alkalmazásokat, élve például a távmunka lehetôségeivel (EU Info Sheet 7.1 2006).

Az országos távközlési szolgáltató (OTE) 2007 januárjában bejelentette, hogy a széles sávú kapcsolatok száma a görög háztartásokban több mint háromszorosára emelkedett, és egész Görögország viszonylatában 13 százalékos szintet ért el (a 2006. év végén a 2005 decemberében nyilvántartott 215 ezerhez képest már 760 ezer széles sávú kapcsolat múködött).

Az Európai Bizottságnál folytatódnak a médiaplurarizmusról és a médiamúveltségról szóló viták. Az új MEDIA 2007 program (2007-2013) jelentôs pénzügyi támogatást nyújt az európai audiovizuális szektornak. Intézkedések elókészítése folyik a mobil televíziózás (a személyi mobilkommunikáció és az audiovizuális tartalomszolgáltatás kombinációja) bevezetésének és terjesztésének támogatására az egész Európai Unióban. Mindez az Európai Bizottság által az információs társadalom fejlesztésére kidolgozott i2010 stratégia középpontjába helyezett digitális konvergencia elôrehaladását példázza (COM 409, 2007; HLG 2006a).

A soknyelvú és innovatív online tartalmak terjesztése terén az első mérföldkövet az Európai Bizottság által kezdeményezett és a gazdasági élet vezetói által 2006-ban elfogadott online filmterjesztési egyezmény (Film Online Charter) alkotja, amely mindenki számára lehetôvé teszi, hogy bárhol és bármikor jó minôségú, megfelelően adaptált tartalmakhoz férhessen hozzá. A következô lépés a felhasználók bizalmának biztosítása az ilyen jellegú új szolgáltatások igénybevételéhez. 2006-ban a mobilszolgáltatások felhasználásának ösztönzése érdekében az Európai Bizottság javaslatára új szabályozást vezettek be a nemzetközi roaming tarifák korlátozására (COM 146, 2007).

Folyamatban van továbbá a „digitális könyvtárak” megteremtésére irányuló kezdeményezés (Digital Libraries Initiative) megvalósítása is. Az Európai Bizottság irányelveket bocsátott ki a kulturális anyagok és a tudományos források online hozzáférhetôvé tételére és digitális formában való megórzésére.

\section{Oktatás és $\mathrm{K}+\mathrm{F}$}

Az innováció és az IKT fejlődése Európában nagymértékben függ a munkaerő e-készségeinek színvonalától, ami magában foglalja az IK'T-eszközökkel kapcsolatos ismereteket és készségeket mind az IKT-profilú vállalatok dolgozói, mind a felhasználók oldalán. A felmérési adatok azonban azt mutatják, hogy az e-készségek tekintetében jelentôs eltérések alakulnak ki. Az EU szintjén hiány van az IKT-szektorban foglalkozta- 
tottak abszolút számát tekintve, továbbá aggasztó hanyatlás mutatkozik az információs technológiai és számítógép-tudományi szakokon tanuló egyetemi hallgatók létszámában is (EU ICT 2006). Úgy túnik, hogy Európa oktatási és szakmai továbbképzési rendszerei nem kielégítően képesek biztosítani a munkaerô versenyképességének fenntartásához és a gazdasági innovációhoz szükséges készségeket. E kérdés további elhanyagolása esetén az európai vállalatok versenyképessége a globális piacon a legtöbb iparágban veszélybe kerül.

A 21. században a gazdasági tevékenység és az értékteremtés leggyorsabban bôvülő forrását a szolgáltatások adják, amelyek a nyugati gazdaságokban a GDP és a munkahelyek körülbelül 70 százalékát biztosítják. A fejlett szolgáltatások és a sikeres innováció menedzselése más készségeket kíván meg, mint az IKT hagyományos szakterületein folytatott tevékenység. A több tudományágat átfogó határterületi ismeretek rendszerére van szükség, a hagyományos IKT-tól a vezetéselméleti stúdiumokig. A szolgáltató gazdaság alapvetố változásokat kíván meg az iskolai és egyetemi tantervekben is (EU ICT 2006). A tudásalapú gazdaság lehetôségeinek teljes kiaknázásához azonban elengedhetetlen, hogy az úgynevezett e-készségek (legalább az alapvetô számítógép-kezelési ismeretek szintjén) beépüljenek a lakosság egészének tudásvagyonába. Az újabb generációk már az iskolai oktatás szerves részeként sajátíthatják el az IK'T felhasználásához szükséges készségeket.

Az IKT által nyújtott elốnyök sikeres kiaknázásában fontos szerepet játszik az oktatási és szakképzési rendszer.

A tudásalapú gazdaságba való átmenet egész életünkre kiterjeszti a különféle oktatási és képzési formákban folytatott tanulást. Ahol a tudás válik a legfóbb értékteremtôvé a gazdaságban, és az elhelyezkedés kulcsfeltétele lesz az emberek munkával töltött egész élete során, a technológiai eszközökre alapozott tanulás (e-learning) is jelentốsen hozzájárulhat az egész életen át tartó tanuláshoz, ami éppen ezen az úton válik megvalósíthatóvá, feltételezi azonban az intézmények hatékony és következetes támogatását és a tanulók felkészülését az IKT-eszközök használatához szükséges készségek elsajátításával.

Az utóbbi néhány év során Görögországban az Oktatás- és Vallásügyi Minisztérium komoly erốfeszítéseket tett valamennyi oktatási intézmény számítógépekkel és internetkapcsolattal való ellátására, párhuzamosan az információs és kommunikációs technológiák (IKT) körébe tartozó ismeretek és alkalmazási készségek oktatásával. A minisztérium oktatási ,intranetként” múködteti a Görög Iskolai Hálózatot, ${ }^{5}$ amely minden óvodát, elemi iskolát, középiskolát és szakmunkásképzó iskolát összeköt egymással, és alapszintú vagy fejlett telematikai szolgáltatásokat nyújt számukra (EKT 2007). E hálózat célja az információs társadalom hálózati technológiájának bevezetése az oktatási rendszer valamennyi szintjén, egy egységes hálózat kifejlesztése révén, amely az ország egész területén az oktatás szolgálatában áll. Így ma lényegében az összes görög iskola felhasználhatja a számítógépeket oktatási és tanulási célokra, és internet-hozzáféréssel is rendelkezik. Az Európai Bizottság megbízásából a számítógépek és az internet iskolai felhasználására vonatkozóan végzett felmérések szerint azonban Görögországban 2006-ban még csak az iskolák 13 százaléka rendelkezett széles

\footnotetext{
${ }^{5}$ http://www.sch.gr/en/
} 
sávú internet-hozzáféréssel. Ez nagy lemaradás: a felmérésben részt vevố huszonhét ország között Görögország az utolsó helyet foglalja el.

A görög kormány erófeszítéseket tesz a tanulók és az elsőéves egyetemi hallgatók olcsó hordozható számítógépekkel való ellátására, továbbá célul tűzte ki, hogy munka melletti továbbképzés útján valamennyi középiskolai tanár számára biztosítani fogják az európai számítógép-használói jogosítvány (European Computer Driving Licence, ECDL) megszerzését.

Állami pénzalapokat különítettek el továbbá a kis- és középvállalkozások múködésének az IK'T-eszközök bevezetésével történố modernizálására, valamint alkalmazottaik kiképzésére az új eszközök használata terén.

Az OPIS legfontosabb prioritási tengelyét az oktatás és a kultúra alkotja.

Oktatás: a kitứzött cél itt az oktatási rendszer átalakítása a digitális kor igényeinek megfelelốen, valamint az új technológiák használatának növelése az oktatásban. Ezen belül fontos részcélok az alábbiak:

1. Iskolai, egyetemi és tudományos kutatói hálózatok létrehozása (az adminisztrációs szolgáltatásokra is kiterjedóen).

2. Az egész életen át tartó tanulás (life-long learning, LLLL) szorgalmazása és ennek érdekében a tanárok és az egyetemi oktatók, valamint az iskolai tanulók és egyetemi hallgatók megfelelő szintú képzésének biztosítása.

Az erre kidolgozott kohéziós akcióterv - az eEurope 2002 és az eEurope 2005 akciótervek javaslataival egybehangzóan - a következó feladatokat tartalmazza:

- Hozzáférés biztosítása az internethez és a multimédia-szolgáltatásokhoz valamennyi iskolában az információs társadalom operatív programjának befejezéséig alacsony költségú berendezések beszerzésével.

- A pedagógusok és az egyetemi oktatók képzése az internetes és más multimédia-alkalmazások, valamint egyéb új technológiák alkalmazására.

Ehhez a feladatkörhöz tartozik:

○ a megfeleló multimédiás oktatási alkalmazások fejlesztése,

o az oktatási szoftveralkalmazások minôségbiztosításának szorgalmazása,

o a digitális könyvtárak hálózatba kapcsolása, valamint

- távoktatási központok létrehozása a pedagógusok és a tanulók képzéséhez.

- A számítógépes írástudás biztosítása a kötelezố oktatásból kilépő tanulók számára.

Mindezeknek a céloknak a megvalósítása a fejlesztési folyamatot felgyorsító új módszerek bevezetésétól függ. Szorgalmazni és támogatni kell a digitális oktatási tartalmak kidolgozását és széles körú hozzáférhetôvé tételét.

Kultúra: az IKT nyújtotta lehetôségeket fel kell használni a görög kultúra és civilizáció menedzselésére, dokumentálására és népszerúsítésére.

A kulturális szektor egyike Görögország alapvetố eloónyös adottságainak más országokhoz képest. A modern IKT által nyújtott lehetôségek a képek, szövegek, hangzó anyagok stb. létrehozására és terjesztésére segítenek kiküszöbölni a nyelvi akadályokat és a földrajzi távolságokat. Az IK'T fontos lehetôségeket nyújt továbbá a görög kulturális és történelmi örökséggel kapcsolatos eszmék és információk terjesztésére, valamint a meglevố értékek digitalizálására. 
Az IKT alkalmazásától mind társadalmi, mind pénzügyi szempontból jelentốs hasznok várhatók a tágabban vett kulturális szektorban, a tudományos és kulturális életben, az oktatásban, valamint a szabadidős iparágak és a gazdaság kontextusában is. A gazdasági elốnyök vagy közvetlenül a kulturális termékek gazdasági hasznosításában, vagy pedig közvetett módon, számos ágazati tevékenység (turizmus, szabadidó-iparágak, kulturális tartalomszolgáltatás, oktatás, kereskedelem stb.) keretében mutatkoznak meg.

Az információs társadalom építése során a kulturális stratégia általános céljai a következók:

- Az IKT terjesztése és felhasználása a görög kulturális vagyon tudományos és adminisztratív jellegú dokumentálására és menedzselésére (beleértve a szellemi jogok kezelését is).

- Az IKT használatával összefüggó új kulturális kifejezési formák támogatása.

- A tartalomipar támogatása

- a kulturális szolgáltatások és a hozzáadott értéket tartalmazó termékek fejlesztése;

○ a kultúrához kapcsolódó gazdasági tevékenységek ösztönzése.

- A kultúra és a múveltség értékeinek tudatosítása

○ a görög kulturális és történelmi örökség (mind az ókori, mind a modern kori értékek) propagandája

$>$ az interneten keresztül és

$>$ más modern kommunikációs hálózatok révén,

○ a különféle szakirányokban specializálódó tudósok, a fiatalok és a nagyközönség aktív részvételének biztosítása.

- A görög nyelv ápolása.

\section{Javaslatok az információs társadalommal kapcsolatos ¡övőbeli kutatásokhoz}

Úgy tûnik, hogy az információs társadalom építésére vonatkozó európai politikai irányelvek és szabályozások követésének változó mértéke, illetve azok eltérô idôpontokban történó bevezetése az egyes tagállamokban különösen hangsúlyozza a kulturális sajátosságok és a nemzeti IKT-környezet szerepét a fejlődésben.

Sok tudós úgy véli, hogy az internet „konvergáló értékeket” teremt (Couger et al. 2001), és az információs technológiák menedzselése minden országban nagyjából ugyanúgy történhet, mint globális szinten. Mások felfogása szerint azonban a kulturális aspektusok, az eltérő üzleti és jogi környezet, a különböző nyelvek és a technológia más-más szintû elérhetôsége folytán nagy különbségek alakulnak ki az egyes országok között (Georgiadou-Siakas 2007, Tractinsky-Järvenpää 1995).

Tsatsou (2005) fontos bírálatot fogalmaz meg az EU jelenlegi politikájával kapcsolatban, rámutatva, hogy az Európai Unió nem kellóképpen ismeri el a tagállamok meglevố kulturális sajátosságait, és nem igazítja hozzá ezekhez megfelelố rugalmassággal az intézkedéseit. Felveti a kérdést, hogy a digitális szakadékok vajon nem hoznak-e létre újabb „kulturális szakadékokat” is, amelyek óhatatlanul kihatnak az európai informá- 
ciós társadalom politikájára, szabályozására és fejlódésére. Hangsúlyozza, hogy olyan európai uniós politikára van szükség, amely számításba veszi valamennyi tagállam társadalmi és kulturális sajátosságait, anélkül, hogy elveszítené általános jellegét, és szem elól tévesztené az EU egészére érvényes célokat.

Az IK'T térhódítását általában a gazdasági növekedés és a munkahelyteremtés eróteljes motorjának tekintik (COM 229, 2005). Az iparosodott országok közötti gazdaságiteljesítmény-különbségeket az IKT-vel összefüggố beruházások és kutatások, az új eszközök tényleges használati szintje, valamint az információs társadalomra jellemző húzóágazatok, köztük a médiaiparágak versenyképessége terén mutatkozó eltérések határozzák meg. A kérdés azonban valószínúleg még bonyolultabb. Valószínú, hogy a mélyen gyökerezố kulturális és társadalmi minták szintén befolyásolják a teljesítménykülönbségeket, és éppen ezért fontos, hogy az EU-ban fokozott hangsúly kerüljön ezekre a kérdésekre. Az alábbiakban a kulturális vonások tudatos figyelembevételének fontosságát igyekszünk kiemelni, néhány korábbi vizsgálat eredményeire támaszkodva.

Hofstede és McCrae (2004) például azt állítják, hogy a kultúra a közösségek viselkedésben megnyilvánuló kollektív (vagyis egy adott társadalmi csoport tagjainak többségénél közös) attribútuma. Hofstede (1994), a kultúraközi kérdések egyik legelismertebb kutatója - 1966-ban 50 országra kiterjedôen, összesen 116 ezer kérdốivvel végzett extenzív kutatásainak eredményei alapján - a különböző kultúrák négy olyan kulcselemét vagy dimenzióját azonosította, amelyek közös problémákat reprezentálnak, ám megoldásuk országról országra más és más lehet, a következố területeken:

- társadalmi egyenlótlenség, „a hatalomtól való távolság” mértéke, hatalmi távolság;

- az egyén és a közösség viszonya (kollektivizmus szemben az individualizmussal);

- a férfiasság és a nóiesség felfogása (nóiesség szemben a férfiassággal);

- a bizonytalanság kezelése, összefüggésben az agresszióval, illetve általában az érzelmek kifejezésre juttatásának kontrolljával (a bizonytalanság elkeriilése).

Az egyes társadalmak „beállítódását” a fenti dimenziókban Hofstede eredetileg 0-tól 100-ig terjedó pontszámokkal értékelte, folyamatos spektrumban, de miután néhány további országot is bevontak a vizsgálatba, száznál nagyobb pontszámok is adódtak (Hofstede 1994). Görögország pontszámai a négy kulturális dimenzióban az alábbiak szerint alakultak.

- Hatalmi távolság: 60 pont - ez viszonylag nagyfokú egyenlótlenségre utal, ami azt jelenti, hogy a görög társadalom elfogadja a hatalom egyenlótlen megoszlását az egyes emberek között, és a kontrollorientált vezetési stílus normálisnak számít. Gil-García és munkatársai (2007) hat állami információmegosztási projekt vizsgálata során úgy találták, hogy a kontrollorientált vezetési stílus a kormányzati környezet jellegzetes vonásaként kulturális értelemben gátló tényezónek tekinthető, és lakossági elfogadása korlátozza a társadalom különféle elốnyökkel és juttatásokkal kapcsolatos elvárásait.

- Kollektivizmus vs. individualizmus: 35 pont - a görög társadalom beállítódása jórészt eleget tesz a kollektivizmus kritériumainak, mivel olyan szoros társadalmi kötelékek jellemzik, amelyekben az emberek különbséget tesznek a csoporton belüliek és a kívülállók között, és a velük azonos csoporthoz tartozóktól elvárják, 
hogy törôdjenek velük. Az EU tagországainak többségére ugyanakkor inkább az individualizmus jellemző.

- Nôiesség vs. férfiasság: 57 pont - Görögországban inkább a férfiasság kritériumai érvényesülnek, ami azt jelzi, hogy a kereset és a munkahelyi elómenetel, az elốléptetések és az extra juttatások tekintetében elônyös vonásnak számít a magabiztos fellépés, a versenyképesség és a materialista szemlélet.

- A bizonytalanság elkerïlése: 112 pont - ez a legmagasabb érték a felmérésben vizsgált valamennyi ország közül, ami arra utal, hogy a zavaros helyzetek és a jövő megítélésekor a görögökre nagyfokú bizonytalanság jellemzô. Az emberek szorgalmasnak, nyughatatlannak, agresszívnak és tevékenynek túnnek, az érzelmek és az agresszió kimutatása elfogadott a társadalomban. A magas bizonytalanságkerülési indexú társadalmakban az emberek rendszerint abszolút igazságokban hisznek, és nem tolerálják a devianciát.

Hofstede munkáját sokat dicsérték és bírálták is. Noha vizsgálatai óta több mint negyven év telt el, az általa felállított sémát mindeddig nem váltotta fel más kulturális osztályozási rendszer (Siakas-Georgiadou 2007). Munkásságának legfóbb erôssége a kulturális dimenziók világos és következetes azonosítása, ami lehetővé teszi a kultúraközi összehasonlításokat.

Az uniós szabályozásokért felelős döntéshozók, akik minden bizonnyal tudatában vannak az EU-tagállamok között fennálló kulturális különbségeknek, valószínúleg számottevố értéket társítanak a többé-kevésbé egységes európai információs társadalom létrehozását szorgalmazó uniós politika érvényesítéséhez. Az újabb trendek számításba vételéhez azonban szükség van tágabb perspektívára is. Az ezzel kapcsolatos reflexióknak ki kell terjedniük azokra az akadályokra is, amelyek hátráltatják az uniós politika követését és a páneurópai online szolgáltatások megvalósítását: az európai információs társadalom kialakulásához különböző megoldások vezethetnek, amelyeknek érdemes megvizsgálni a költségeit és kockázatait.

\section{Irodalom}

Agrafiotis D. 1997. Information society and Greek society: Socio-cultural and political incompatibilities, IFIP TC9 WG 9.2/9.5 International Conference on Culture and Democracy Revisited in the Global Information Society. Corfu, GRECE (08/05/1997).

Beroggi, G. E. G. - Täube, V. G. - Lévy, M. 2005. Statistical indicators for monitoring and controlling the ICT system. International Journal of Technology, Policy and Management, Vol. 5, No. $1,93-120$

Boufeas, G. - Halaris, I. - Kokkinou A. 2004. Business plans for the development of e-government in Greece. An appraisal. United Nations Thessaloniki Centre for Public Service Professionalism (UNTC) Occasional Papers, No 5.

Cap Gemini 2006. Online Availability of Public Services: How Is Europe Progressing? Web Based Survey on Electronic Public Services. Report of the 6th Measurement, June (http://www.observe.gr/files/meletes/Capgemini\%20-\%20egov_benchmarking_June06.pdf).

Castells, Manuel 1996. The Rise of the Network Society. Oxford, Blackwell.

CCeGov 2007. Designing efficient and effective e-public services: developing a systematic understanding of citizen-consumers and their needs. GR: 2nd International cc:eGov Workshop - 
Organisational change for citizen-centric eGovernment, 20-21 February, Athens, Greece (http://www.ccegov.eu/?Page=Workshops).

COM 409 2007. „i2010 - Strengthening the Internal Market for Mobile TV”, communication from the commission to the council, the European parliament, the European economic and social committee and the committee of the regions. Brussels, 18.07.

COM 146 2007. „i2010 - Annual Information Society Report 2007”, communication from the commission to the council, the European parliament, the European economic and social committee and the committee of the regions. Brussels, 30. 03.

COM 229 2005. „i2010 - A European Information Society for growth and employment”, communication from the commission to the council, the European parliament, the European economic and social committee and the committee of the regions. Brussels, 01.06

COM 173 2006. i2010 e-government action plan: Accelerating e-government in Europe for the benefit of all. Brussels, 25. 04.

Couger, J. D. - Halttunen, V. - Lyytinen, K. 1991. Evaluating the motivation environment in Finland compared to United States - a survey. European Journal of Information Systems, Vol. 1 , No 2, 107-112.

E-readiness 2007. The 2007 e-readiness rankings: Raising the bar. A white paper from the Economist Intelligence Unit, written in co-operation with The IBM Institute for Business Value.

EIU 2007. The rising stakes of digital leadership. The Economist Intelligence Unit, 26 April (http://ec.europa.eu/information_society/eeurope/i2010/docs/annual_report/2007/country factsheets/2007_factsheet_gr.pdf).

EU Info Sheet 7.1 2006. i2010-2005-2006: A period of rapid market developments, May. Fact sheets: 12,35 .

EU Info Sheet 7.2a 2006. i2010 - The world's economies depend on Information \& Communication Technologies (ICT), May. Fact sheets: 6, 35.

EU Info Sheet 7.2b 2006. i2010 - The Adoption of Information \& Communication Technologies (ICT) by Business, May. Fact sheets: 6, 35 .

EU Info Sheet 7.3 2006. i2010 Inclusion: Policies and technologies that improve public services. Fact sheets 6, 12, 35 .

EU Info Sheet 7.4 2006. i2010 - What comes next? Plans for 2006-2007, May. Fact sheets: 6, 35.

EU-Report 2007. i2010 - Annual Report 2007.

http://ec.europa.eu/information_society/eeurope/i2010/

European Commission 2007. Greece - i2010 Annual Report. http://ec.europa.eu/information_society/eeurope/i2010/

European Commission 2006. Information Society and Media Directorate General Lisbon Strategy and Policies for the Information Society, Lisboa Strategy and i2010, Use of Computers and the Internet in Schools in Europe 2006, Country Brief. Greece. 6/2006.

Eurostat 2007. http://epp.eurostat.ec.europa.eu/portal/page?_pageid=1090,30070682,1090 _33076576\&_dad=portal\&_schema=PORTAL

Greek Observatory 2007. (http:// www.observe.gr/).

Greek IS Observatory research 2007. Information Society Politics Greece (http://www.observe.gr/page/default.asp?la=2\&id=183).

Greek IS Observatory 2007a. Best processes of establishment and operation of businesses concerning the transactions that are realised with the public sector-Government to Business, Foundation for Economic and Industrial Research (http://www.observatory.gr/files/meletes/BP_TPE_P3_EN.pdf).

Greek IS Observatory 2006. Study of the ICT sector in Greece: Current Situation and Future Trends, Foundation for Economic and Industrial Research, Deliverable 14, Prospects of 
the ICT sector in Greece - policy implications, October

(http://www.observe.gr/files/meletes/ICT_14_final_eng.pdf).

GR-DeAN 2003. The National Network on Design for All (http://www.e-accessibility).

$H L G$ 2006a. The Challenges of Convergence, European Commission Discussion paper, i2010 High Level Group, 12. 12.

HLG 2006b. The economic impact of ICT: evidence and questions, European Commission Discussion paper, i2010 High Level Group, 20. 04. 2006.

Hofstede G. 2001. Culture's consequences: comparing values, behaviours, institutions, and organisations. -2nd Ed.Thousand Oaks, California - London, Sage Publications.

Hofstede, G. - McGrae, R. R. 2004. Personality and Culture Revisited: Linking Traits and Dimensions of Culture. Cross-Cultural Research, Vol. 38. Issue 1, 52-85.

ICAP 2006. Greece in Figures, Greek Financial Directory (http:// www.financial-directory.gr vagy http://www.icap.gr).

ICTPSP 2007. entire CIP program

(http://ec.europa.eu/enterprise/enterprise_policy/cip/index_en.htm)

ICT Policy Support Programme (http://europa.eu/ict_psp)

(http://ec.europa.eu/information_society/activities/ict_psp/index_en.htm).

EU Information Society and Media: ict_policy_presentation_2007

IDABC 2007. European eGovernment News Roundup, N. 17216 January. http://ec.europa.eu/idabc/egovo

DeMunter Christopher 2006. How skilled are Europeans in using computers and the Internet? EuroStat manuscript 07. 06. ISSN 1561-4840, Catalogue number: KS-NP-06-017-EN-N.

Gil-Garcia, J. R - Chengalur-Smith, I. - Duchessi, P. 2007. Collaborative e-Government: impediments and benefits of information-sharing projects in the public sector. European Journal of Information Systems, No. 16, 121-133.

Grimsley, M. - Meehan, A. 2007. e-Government information systems: Evaluation-led design for public value and client trust. European Journal of Information Systems, No. 16, 134-148.

OECD 2007. Economic survey of Greece 2007. Organisation for Economic Co-Operation and Development, 30 May (www.oecd.org/eco/surveys/greece).

SCP-5 2007. Administration to Business (A2B). The European strategy promotes e-Government. Single Contact Point 5, European Project.

Siakas, K. - Georgiadou, E. 2007. Knowledge Sharing in Virtual and Networked Organisations in Different Organisational and National Cultures. In Ettore Bolisani (ed.): Building the Knowledge Society on the Internet. Idea Publishing.

Stephanidis, C. (ed.) 2004. Universal access and equal participation of people with disabilities in the Information Society in the context of the operational programme Information Society of the 3rd Community Support Programme. Secretariat for the Information Society, Hellenic Ministry of Economy and Finance: Framework for current activities promoting e-inclusion and e-accessibility,

(http://www.infosoc.gr/NR/rdonlyres/0B306F9C-A8194F96ABB1A21945D1D2B3/1092/ final_report.pdf.)

Syzefxis 2007. http://www.syzefxis.gov.gr/

Tractinsky-Noam-Järvenpää 1995. Information Systems Design Decision in a Global versus Domestic Context. MIS Quarterly, December, 507-529.

Tsatsou P. 2005. Civil Society in Greece: Shaping new Digital Divides? The Digital Divides as 'Cultural' Divides. Implications for Closing Divides, ESRC Seminar on 'Bridging the Digital Divides', Oxford Internet Institute, UK, 4 March.

http://www.oii.ox.ac.uk/collaboration/seminars/20050304_Panayiota_Tsatsou_Paper.pdf 
Tsekos, T. 2001. UNTC, Greece: Building an enterprise architecture for public administration: a high-level data model for strategic planning. Strategic Planning in Public Services, a Project of CARIFORUM and the European Development Fund.

http://unpan1.un.org/intradoc/groups/public/documents/CARICAD/UNPAN010295.pdf

Zambarloukos, S. - Constantelou, A. 2002. Learning and skills formation in the new economy: evidence from Greece. International Journal of Training and Development, Blackwell Publishers, vol. 6 (4), 240-252.

\section{Görög nyelvü források}

CSF Citizens' Online Information System 2007. http://www.info3kps.gr

e-Business W@tch 2006. ICT and e-Business in the Telecommunication Industry: ICT adoption and e-business activity in 2006. The European Commission, Enterprise \& Industry Directorate General, Sector Report No. 9

http://ec.europa.eu/comm/enterprise/ict/policy/watch/index.htm, www.ebusiness-watch.org

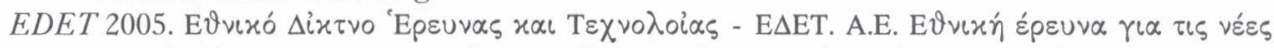

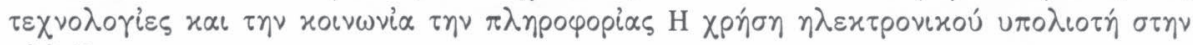
$E \lambda \lambda \dot{\alpha} \delta \alpha$.

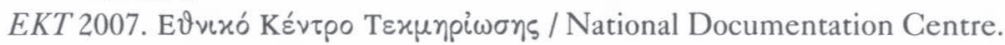

EU ICT 2006. Fostering the competitiveness of Europe's ICT industry, EU ICT Task force Report, November.

Kep 2007. http://www.kep.gov.gr/

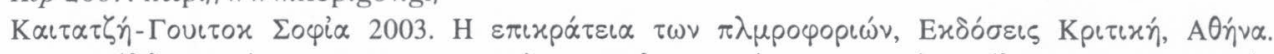

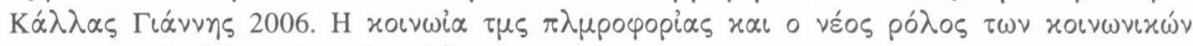

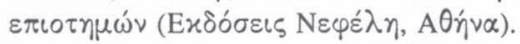

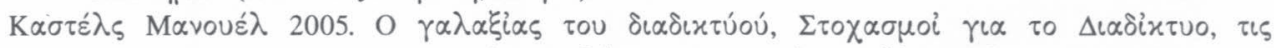

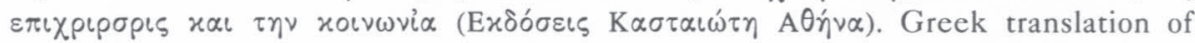
Castells, Manuel (2001): The Internet Galaxy. Reflections on the Internet, Business and Society.

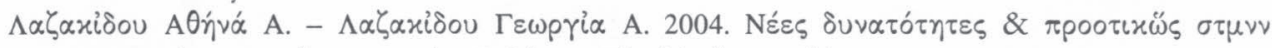

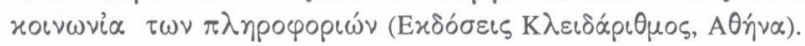

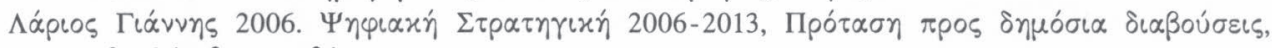

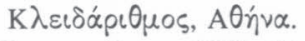

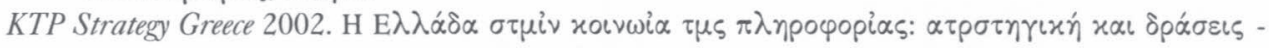

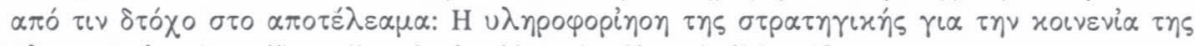
$\pi \lambda \mu \rho \circ \varphi \circ \rho i \alpha \zeta$. http://broadband.cti.gr/download/strathgikh.pdf

eInclusion Greece 2007.

http://ec.europa.eu/information_society/activities/einclusion/policy/a_documents/pdf/ greece_einclusion.pdf

Infosoc 2007. Information Society, the official Greek portal for the I.S.: Managing authority for operational programme. http://www.infosoc.gr/infosoc/el-GR/

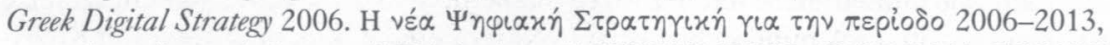
http://www.infosoc.gr/NR/rdonlyres/A13F889F-DE92-4DCF-B64A-37351BFC69B9/ 3053/ktp_all.pdf, http://www.infosoc.gr/NR/rdonlyres/A13F889F-DE92-4DCF-B64A-37351BFC69B9/660/ GreekDigitalStrategy20062013.pdf 


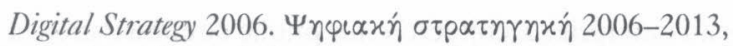
http://www.infosociety.gr_digital_strategy

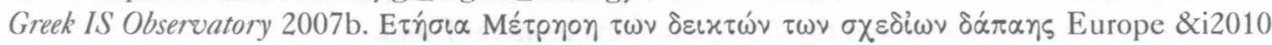

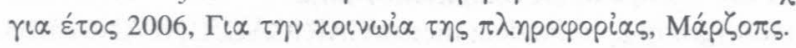

